\title{
Current Advances in Virus-Like Particles as a Vaccination Approach against HIV Infection
}

\author{
Chongbo Zhao ${ }^{1}$, Zhujun Ao ${ }^{1}$ and Xiaojian Yao ${ }^{1,2, *}$ \\ 1 Laboratory of Molecular Human Retrovirology, Department of Medical Microbiology, Faculty of Medicine, \\ University of Manitoba, Winnipeg, MB R3E 0J9, Canada; chongbozhao@yahoo.com (C.Z.); \\ Zhujun.Ao@umanitoba.ca (Z.A.) \\ 2 Department of Microbiology, School of Basic Medical Sciences, Central South University, \\ Changsha 410078, Hunan, China \\ * Correspondence: Xiao-Jian.Yao@umanitoba.ca; Tel.: +1-204-977-5677; Fax: +1-204-789-3926
}

Academic Editor: Diane M. Harper

Received: 17 November 2015; Accepted: 18 January 2016; Published: 22 January 2016

\begin{abstract}
HIV-1 virus-like particles (VLPs) are promising vaccine candidates against HIV-1 infection. They are capable of preserving the native conformation of HIV-1 antigens and priming CD4+ and CD8+ T cell responses efficiently via cross presentation by both major histocompatibility complex (MHC) class I and II molecules. Progress has been achieved in the preclinical research of HIV-1 VLPs as prophylactic vaccines that induce broadly neutralizing antibodies and potent $T$ cell responses. Moreover, the progress in HIV-1 dendritic cells (DC)-based immunotherapy provides us with a new vision for HIV-1 vaccine development. In this review, we describe updates from the past 5 years on the development of HIV-1 VLPs as a vaccine candidate and on the combined use of HIV particles with HIV-1 DC-based immunotherapy as efficient prophylactic and therapeutic vaccination strategies.
\end{abstract}

Keywords: HIV-1; virus-like paticles (VLPs); vaccine; dendritic cells-based immunotherapy; adjuvants; dendritic cells

\section{Introduction}

More than 30 years have passed since the discovery of the human immunodeficiency virus (HIV) in 1983 [1,2], and the development of an effective, safe and affordable HIV vaccine is still the first priority for achieving ultimate control of the worldwide HIV pandemic. Since 1987, more than 30 vaccine candidates have been tested in over 230 clinical trials [3,4], with only a few of these trials reaching phase IIb/III [5]. None of these candidates showed efficacy, except for the RV144 vaccine trial carried out in Thailand that reported an estimated efficacy of 31.2\% [5,6]. The RV144 trial shed light on eliciting broadly neutralizing antibodies and structural-based vaccine design for developing an effective HIV-1 vaccine.

Several types of traditional vaccine strategies, such as live attenuated virus, inactivated virus and recombinant viral vectors, have been disappointing for the development of HIV vaccines. Live attenuated virus vaccines have been a great success in preventing small pox, measles and poliovirus infections, but this strategy has not been adopted for an HIV vaccine due to safety concerns, as live attenuated HIV may revert to a virulent pathogenic form, and the virus genome may integrate into the recipient's genome $[7,8]$. Inactivated virus vaccines have been proven successful for controlling the prevalence of influenza and poliovirus worldwide. Although inactivated HIV has long been considered as a vaccine candidate, especially for therapeutic vaccines proposed by Jonas Salk in 1987 [9], it has been shown that an inactivated virus vaccine is a disappointing approach for HIV vaccine development. The traditional inactivation method such as formaldehyde treatment causes a loss of antigenicity, and virus inactivated using alternative inactivation approaches induced only modest neutralization [10]. It has 
been demonstrated that protection against SIV observed in macaques immunized with inactivated SIV was due to presence of host HLA-I antigen residue instead of SIV-specific immune responses [11-13]. Additionally, bio-safety issues in production and the risk of incomplete inactivation of HIV are also disadvantages of an inactivated HIV vaccine. Several recombinant viral vector and DNA vaccine candidates tested in clinical trials showed poor immunogenicity or no efficacy [14-17].

Recent efforts in HIV vaccine development have aimed at the induction of broadly neutralizing antibody and T cell responses. HIV-1 virus-like particles (VLPs) are highly attractive vaccine candidates due to their capability of presenting native functional Env spikes on the surface, which are able to elicit neutralizing antibodies. Additionally, HIV-1 VLPs can be captured by DCs and presented by both MHC class I and MHC class II molecules without leading to infection or replication [18-20]. VLPs are self-assembling, non-infectious, non-replicating genome-less virions that retain their natural structure and conformation and display authentic antigen [21-25]. Due to their particulate structure, VLPs can be taken up efficiently by APCs, especially DCs, leading to the induction of strong cellular and humoral immune responses [18,26-31]. At present, there are four VLP-based licensed vaccines in the market such as HBsAg VLPs (Engerix-B®by GlaxoSmithKline, Recombivac HBßby Merck and GenHevacB®by Sanofi-Pasteur, etc.), HPV VLPs (Cervarix®by GlaxoSmithKline, Gardasil@by Merck), HEV VLPs (Hecolin®by Xiamen Innovax Biotech) as well as Influenza virus VLPs (Flublok®by Protein Sciences Corporation), and a number of VLP-based vaccine candidates in clinical development [24,32].

Moreover, a growing endeavor has been focused on the development of therapeutic HIV-1 vaccines based on dendritic cells (DCs), which are able to restore T cell responses, limit virus replication and are financially more affordable as an alternative to life-long antiretroviral therapy (ART). DCs are the most potent professional antigen-presenting cells that play a pivotal role in shaping the magnitude and duration of immune responses [33-36]. DC-based therapy has been broadly tested for anti-tumor and anti-viral therapy [37-41]. In 2010, the US FDA approved the first DC-based cancer vaccine [42]. DCs play a central role in HIV infection. It is expected that DC-based vaccine approaches will induce strong CD4+ T cell responses that are critical for a sustained and effective HIV-specific CD8+ CTL response to suppress HIV replication, while DCs also contribute to virus dissemination.

We briefly review the current progress in the development of the HIV-1 VLP vaccine and DC-based HIV-1 immunotherapy as well as the features of these two immunization strategies and, we also emphasize that the combination of these two immunization strategies may be a prophylactic and/or a therapeutic vaccination approach against HIV-1 infection.

\section{Current Progress in HIV-1 VLP as a Prophylactic Vaccine Candidate}

\subsection{HIV-1 Envelope Glycoprotein in VLPS as an Immunogens}

For an effective prophylactic HIV-1 vaccine, the capability of eliciting broadly neutralizing antibodies (bNAbs) that can inhibit the infection of diverse HIV strains is one of essential elements $[16,43]$. bNAbs bind to the native envelope glycoprotein spikes on the surface of HIV-1 and interfere with receptor engagement and virus entry into the cell $[43,44]$. Over the past 20 years, varieties of bNAbs have been isolated from naturally infected donors whose sera has shown potent cross-strain HIV-1 neutralization, and Env epitopes targeted by bNAbs have been identified. b12 and 2G12 directly recognize the exterior portion of the gp120 protein [45-48], while 2F5, 4E10 and Z13 target the transmembrane gp41 protein [49-51]. Recent studies demonstrated the blockade of the CD4 binding site by VRC01/2, VRC03 and HJ16 [52,53], the binding of PG9 and PG16 to discontinuous epitopes located in the trimeric structures [54], the neutralizing activities of a mAb against the V3 loop [55-57]. It is also noteworthy that more and more new bNAbs were described in the most recent years, such as the recognition of a glycan-dependent epitope at the interface of gp41 and gp120 of properly formed and cleaved trimmers by PGT151 [58,59], PGT121 blocking V3 loop of gp120 [60,61] and binding to a conformational but yet to be defined epitope by 3 BC176 [62,63]. Therefore, Env has 
been considered as the principal antigen for HIV-1 VLP vaccine development, and great effort has been made to improve its ability for priming bNAb responses.

However, the poor accessibility to the neutralizing epitopes strongly inhibits the development of bNAbs, due to a number of features of Env. Heavy glycosylation results in the formation of a glycan shield on the surface of Env trimer, which reduces access to the protein epitopes [64-67]. Moreover, conserved neutralizing sites, such as epitopes in the CD4-binding site and the membrane-proximal external region (MPER), hide within the trimer. The CD4-binding site is not fully exposed and undergoes a conformational change upon its binding to CD4 [67]. Similarly, the exposure of MPER is coupled to the fusion between the virus and host cell membranes $[68,69]$. In addition, the low density of native Env spikes displayed on the viral surface, as well as the contamination with non-functional Env, also contribute to the inaccessibility of neutralizing epitopes [70-75].

To elicit a high titer of anti-Env neutralizing antibodies, enhancing the exposure of the neutralizing epitopes in Env on the surface of the VLPs could be an effective strategy. The immunization of rabbits with VLP displaying Env trimers showed that glycan-deficient patches allowed the development of tier 2 neutralizing antibodies to native spikes [76]. Elimination of a glycosylation site in Loop D and two glycosylation sites in variable region 5 of Env enabled Env to bind to and to activate B cells expressing germline-reverted BCRs of two potent VRC01 class broadly neutralizing antibodies [77,78]. Therefore, the absence of glycan facilitates the exposure of the neutralizing epitopes in Env, indicating that removing glycosylation sites in highly conserved epitopes of native Env could be an effective pathway to encourage bNAb development and to reinforce the potency of Env-bearing VLP candidates. Additionally, the direct presentation of conserved epitopes of Env on the surface of VLPs, avoiding the conformational masking of the neutralizing sites, may facilitate the induction of the bNAb response. A recent study showed that chimeric VLPs, a bovine papillomavirus (BPV) displaying gp41, presented MPER and induced 2F5 and 4E10 epitope-specific antibodies in mice, resulting in partial neutralization of clade B and clade $C$ virus [79]. Another study showed that gp41 peptide arrays were presented at a high density on the surface of bacteriophage VLPs designated AC205 and induced cross-strain neutralizing antibodies to different strains of HIV-1 pseudovirus at various levels following immunization in mice [80].

It is widely accepted that the native Env trimer, rather than the non-functional forms of Env such as the uncleaved gp160 and gp41 stumps, elicited neutralizing responses [70]. HIV-1 presents approximately 14 Env trimers at a Gag:Env ratio of 60:1 on the surface of a native virion with an irregular distribution pattern $[74,75,81]$. The elimination of aberrant Env could be helpful to reduce non-neutralizing antibody development. "Trimer" VLPs bearing pure native Env spikes were generated by enzyme digestion to remove antigenic interference of non-functional Env, and the data showed that the trimer VLPs induced tier 2 neutralizing antibodies [76,82]. Because the low density of Env spikes on the VLP surface may negatively affect affinity selection [73,81], a high efficiency of HIV-1 envelope protein expression and presentation on the surface of the VLPs could benefit the induction of anti-Env NAbs. For this purpose, VLPs expressing recombinant HIV-1 Env with trimeric conformation was produced in insect cells using a baculovirus expression system, and sera from immunized mice showed a high reactivity with HIV specific antigens but a disappointing neutralization activity to HIV pseudovirus [83].

\subsection{HIV-1 Gag Proteins in VLPs as Immunogens}

Gag polyprotein is an essential component of HIV-1 VLPs that is capable of self-assembly, giving rise to VLPs without other viral proteins or virus RNA, which provides a platform for the presentation of envelope antigens [84-87]. Moreover, HIV-1 Gag has been considered as an attractive HIV antigen. In 2000, it was reported that HIV-1 p55gag VLPs were capable of priming strong long-lasting CTL responses against multiple HIV-1 p55 ${ }^{\text {gag }}$ epitopes in rhesus macaques [31]. A previous study showed that yeast-expressed HIV-1 p55gag VLPs were efficiently incorporated into DCs, and VLP-loaded DCs activated Gag-specific CD8+ T cells, inducing a CTL response in chronically HIV-infected patients [30]. It has been reported that HIV-1 Pr55gag VLPs induced HIV-1-specific CD4+ and CD8+ T cell responses, 
as well as antibody response with cross-clade but partial neutralizing reactivity to primary field isolate in BALB/C mice [88]. Recent studies demonstrated that Gag-VLP efficiently induced the activation and maturation of DCs and the production of pro-inflammatory cytokines, which subsequently mediated NK immune responses [89]. Moreover, the same research group also reported that HIV-1 Gag-VLP up-regulated the expression of APOBEC3G and 3F in an IFN- $\alpha$-dependent manner in human DCs and inhibited HIV-1 replication in both DCs and CD4+ T cells [90]. These findings revealed that in addition to a platform for displaying Env antigen, HIV-1 Gag is also a promising HIV-1 vaccine component for prophylactic and therapeutic purposes.

\subsection{Combinations of HIV-1 Proteins in VLPs as Immunogens}

Although native Env trimers are used as the principal antigen for HIV VLP vaccines, suggestive evidence for a cross-talk between different lentiviral proteins in immune responses has also been observed. Several independent studies in which non-human primates immunized with SIV Gag and followed by SIV or SHIV challenge showed an elevated Env-specific or neutralizing antibody response after virus challenge in Gag-immunized macaques [91-93]. One study demonstrated that the anti-Env antibody increased significantly in mice immunized with an adenoviral vector or a DNA vaccine against Gag-Pol and boosted with a VLP bearing Gag-Pol and Env [94]. In addition, in the same study, an enhancement of the Env antibody response to VLP immunization in recipient mice was observed after the adoptive transfer of CD4+ T cells from Gag-Pol-immunized mice. Although the mechanism of the cooperation between the immune response to Env and that to Gag-Pol remains to be investigated, it has been suggested that "intrastructural help" could be one explanation, according to which it was speculated that whole viral particle may be taken up by naïve B cells and peptides of both Env and Gag may be presented on the MHC-II molecules of B cells, therefore Gag-specific T helper cells could provide cognate help for Env-specific B cells and thus facilitate Env-specific antibody responses [94]. This information reminds us that besides HIV-1 Env glycoprotein presented on the surface of VLPs. Other components of HIV-1 VLPs play a synergistic role that contribute to a more profound protective antibody responses. In a recent study, two attenuated poxvirus vectors expressing soluble gp140 and Gag-Pol-Nef as VLPs were employed as HIV-1 vaccine candidates and tested in mice, in which highly polyfunctional Env-specific CD4 responses, in the case of gp140, and high magnitude Gag-specific CD8 $\mathrm{T}$ cell responses, in the case of Gag-Pol-Nef, were elicited, respectively, and antibody responses against gp140 and p17/24 were observed as well [95]. Additionally, this study indicated that the combination of these two vectors expressing different HIV-1 antigens led to more balanced CD4 and CD8 $\mathrm{T}$ cell responses and better humoral and cellular immune responses. Therefore, optimization of the antigen composition pattern could be an efficient pathway to improve the immunogenicity and potency of HIV-1 VLP vaccines. In addition, these observations indicate the advantage of using VLPs as a vaccine approach.

\subsection{Incorporation of Different Adjuvants into HIV-1 VLP to Enhance Immune Responses}

In a series of recent studies, the adjuvant effects of different biological agents were tested to improve the immunogenicity and potency of HIV-1 VLPs.

Studies have shown that cytokines may play a role as effective adjuvants to enhance immune responses [96-99]. Anti-Env antibodies with strengthened avidities were induced in rhesus macaques vaccinated by a heterologous prime-boost regimen with a co-expression of GM-CSF and antigens [100]. It has been indicated that GM-CSF could promote the avidity of the antibody by recruiting and activating antigen-presenting cells (APCs), such as myeloid dendritic cells, which are important to elicit robust immune responses $[100,101]$. It has been demonstrated that IL-4 played a critical role in the regulation of Th2 lineage differentiation and thus benefited humoral immune responses [102]. Previous studies have shown that the combination of GM-CSF and IL-4 induces the differentiation and optimization of growth of DCs [103-105]. GIFT4 is a fusion protein of GM-CSF and IL-4, which has been shown to lead to an alteration in the pro-immune cytokine secretory profile and a robust B cell mitogenic response [106]. A recent study showed that GIFT4 was successfully anchored into HIV-like 
particles presenting a high density of Env as a co-stimulatory factor, forming a novel adjuvanted chimeric VLP as a HIV VLP vaccine candidate [107]. The immunogenicity of this novel chimeric HIV-1 VLP was evaluated in guinea pigs via an intramuscular priming-intranasal boosting route, and results showed that improved systematic and mucosal antibody responses with augmented avidities and broadened neutralizing breadth were generated, although only partial neutralization was achieved, compared to un-adjuvanted HIV-1 VLPs, neutralizing reactivity to certain strains of clade B and clade $C$ virus was significantly enhanced. This research demonstrated the potential of GIFT4-containing HIV VLPs as a promising HIV vaccine candidate, as well as the positive role that cytokines could play as adjuvants enhancing the immunogenicity of HIV-1 VLPs.

Flagellin was tested as an adjuvant incorporated into HIV-1 VLPs in a guinea pig model [108]. Flagellin is the principal protein that forms the highly complex flagellar structures named flagellum that extend from the outer membrane of Gram-negative bacteria. A conserved site on flagellin can be recognized by Toll-like receptor 5, and it has been observed that flagellin is a potent and effective adjuvant in both humans and non-human primates [109-112]. It has been shown that HIV-1 VLPs with membrane-anchored flagellin induced a broadened neutralization activity against five strains from clades $B$ and $C$, and the adjuvant effect of flagellin contributed to the enhancement of HIV-1 VLP immunogenicity.

Targeting antigens selectively to DCs has been proposed and studied as a novel approach to improve the effectiveness and potency of vaccines [113]. The CD40 ligand has been constructed into HIV-1 and SHIV VLPs successfully to target antigens to the CD40 receptors on DCs to enhance HIV-1-specific immune responses [114,115]. In these studies, the biological properties of these VLPs were characterized in vitro and immunogenicity was investigated in mice, which indicated that CD40L-containing VLPs could target to DCs and promote the activation of DCs and that CD4+ and CD8+ T cell responses were stimulated efficiently.

\subsection{Mucosal Immunity against HIV-1 Induced by VLPs Bearing HIV-1 Antigen}

HIV is predominantly transmitted venereally, with infection initiating at a mucosal surface such as the vaginal or rectal mucosa [116-118], and HIV pathogenesis studies have demonstrated that early infection at a mucosal portal of entry is a bottleneck for HIV infection [119]. Mucosal secretory IgA plays an essential role in preventing HIV infection at the mucosal portals of entry [120,121]. Therefore, various measures have been adopted to induce effective HIV-1-specific mucosal immunity. It has been shown that the nasal cavity is a critical site for induction of both mucosal and systemic immune responses, as intranasal immunization has been shown to be effective for preventing influenza infection [122-128]. Moreover, it has been reported that VLPs have shown a satisfactory track record in intranasal immunization due to their capabilities in efficiently targeting APCs and promoting the induction of potent immune responses [29,127,129-135]. The immunogenicity of chimeric HIV-1 VLP with flagellin anchored on the surface was tested in guinea pigs via intranasal immunization, where enhanced mucosal immunity was observed [108]. In another study, intranasal administration was adopted to test the immunogenicity of an HIV-1 VLP based on Gag protein consisting of whole HIV gp120/140 envelope protein derived from an Ugandan clade A field isolate in rhesus macaques, which showed that sequential intranasal and intramuscular administration of HIV VLPs, in contrast to intranasal administration alone, was able to elicit humoral immune responses at the systemic and the vaginal level, but suggested that intranasal administration may be priming the humoral mucosal immunity for subsequent intramuscular immunization [136]. Intranasal immunization has also been employed as a boosting immunization route. The immunogenicity of GIFT $_{4}$-containing HIV-1 VLPs was tested in guinea pigs through an intramuscular priming-intranasal boosting route and mucosal immunity was evaluated by measuring the titer of IgG and IgA at mucosal sites, where an increased level of antibodies was observed, indicating that immunity at the mucosal site was successfully elicited [107]. It has been demonstrated that BPV VLP is an ideal mucosal delivery vector that protects antigens from degradation in the digestive tract and functions as an adjuvant, inducing both mucosal and systemic immune responses through the oral immunization route [137-142]. The 
oral immunization route was adopted to test the immunogenicity of a HIV-1 MPER domain displaying bovine papillomavirus (BPV)-based VLPs in mice, and HIV-specific systemic immune responses and mucosal immune responses at the intestinal mucosa were successfully induced, although a high titer of antibodies at the vaginal mucosa was not detected [79]. Therefore, various pieces of evidence have demonstrated that HIV VLPs are capable of eliciting mucosal immune responses, although protection at the mucosal site needs to be further validated by challenge with HIV-1, for example.

\section{HIV-1 VLPs as Potential Antigens in DC-Based HIV-1 Therapeutic Vaccination}

\subsection{Current Progress of DC-Based HIV-1 Therapeutic Vaccine}

A DC-based therapeutic vaccine is intended to restore HIV-1-specific T cell responses, control viral replication or even eradicate the HIV reservoir in HIV-infected individuals. A successful DC-based therapy shall be able to persistently suppress HIV replication efficiently without life-long cART, which is considered as a "functional cure". A series of in vitro tests demonstrated that T cell immune responses can be induced by DCs loaded with various HIV antigens. It has been reported that monocyte-derived DCs pulsed with aldrithiol-2-inactivated autologous virus stimulated the proliferation of both CD4+ and CD8+ T cells in patients, as well as CTL responses of CD8+ T cells [143]. Subsequently, another two studies reported ex vivo autologous inactivated HIV-1 production for a clinical DC-based therapeutic immunization, and both of these studies demonstrated that autologous inactivated HIV-1 virus-based immunogen production fulfilled cGMP and the expected specifications and could be used for the purpose of clinical trials [144,145]. DCs pulsed with HIV-1-derived proteins have been studied. DCs pulsed with HIV-1 Gagp55-liposome complexes have been shown to be capable of stimulating PBMCs from HIV-1-negtive individuals and inducing HIV-1-specific CD8+ T cell responses [146]. DCs loaded with synthetic peptides representing HIV-1-specific HLA class I epitopes activated blood-derived autologous CD8+ T cells [147]. HIV-1 antigen-encoding mRNA electroporation has been demonstrated to be a more effective technique, and HIV-1-specific CD4+ and CD8+ T cell responses were stimulated by DCs from both infected and uninfected individuals electroporated with mRNA encoding Gag p24 and Gag p55, Rev and Nef, and Env, Nef, as well as Tat [148-154]. Additionally, studies have demonstrated the T cell activation capabilities of DCs pulsed with HIV-1 antigen expressed through recombinant viral vectors and HIV-1 antigen-displaying nanoparticles [155-159].

Potent immune responses against HIV-1 have been demonstrated by animal studies in which animals were immunized with DCs bearing inactivated virus, HIV-1 viral lysate or envelope glycoproteins [160-163]. To date, 17 clinical trials of DC-based HIV-1 immunotherapy have been reported, as shown in Table 1 [154,164-179]. In these clinical trials, DCs were loaded with a variety of types of HIV-1 antigens, including AT-2- or heat-inactivated HIV-1, HIV-1 peptides, HIV-1 antigen-encoding RNA or HIV-1 antigen-expressing recombinant viral vectors. All of these clinical trials demonstrated an excellent safety profile of the DC-based HIV-1 therapy, with only minor local side effects as reported in some clinical trials. No severe side effects or induction of autoimmunity were reported. Different levels of virological responses to immunization were observed. Studies performed with autologous antigens showed variable levels of virological responses [165,166,171,172,175], which correlated with consistent enhanced HIV-1-specific T cell immune responses, and clinical trials performed with heterologous antigens failed to show any virological responses to immunization, although moderate to strong immune responses were observed in these studies, such as increased CD4+ T cell count, HIV-1 antigen-specific CTL responses and IFN- $\gamma$ production $[164,167-170,176]$. All of the 17 clinical trials suggested that DC-based immunotherapy in HIV-1 infection is able to induce HIV-1-specific immunological responses, including both HIV-1-specific CD4+ and CD8+ T cell responses. Although prominent variability existed in all aspects of these clinical trials, including the choice of HIV-1 antigens, preparation of DC, design of clinical trial and immunological assessment, the results of these clinical trials are promising and inspiring, providing us with clues for the further development of DC-based HIV-1 therapy or HIV-1 vaccination strategy. 
Table 1. Reported clinical trials of dendritic cell (DC)-based HIV-1 therapeutic vaccine.

\begin{tabular}{|c|c|c|c|c|c|c|c|c|}
\hline Author [Ref.] & HIV-1 Antigens & DC Type & DC Maturation & Subjects & Treatment & Loading Strategy & Route & Schedule \\
\hline Kundu et al. [164] & $\begin{array}{l}\text { Recombinant HIV-1 } \\
\text { gp160 or synthetic env, } \\
\text { gag, pol peptides }\end{array}$ & $\begin{array}{c}\text { allogeneic or } \\
\text { autologous blood } \\
\text { DC }\end{array}$ & - & $N=6$ & - & Pulsing & I.V. & $\begin{array}{c}\text { 6-9 doses at } \\
\text { monthly intervals }\end{array}$ \\
\hline Lu et al. [165] & $\begin{array}{l}\text { AT2 inactivated } \\
\text { autologous virus }\end{array}$ & autologous MDDC & IL-1 $\beta$, IL-6, TNF- $\alpha$ & $\mathrm{N}=18$ & - & Pulsing & S.C. & 3 doses every 2 weeks \\
\hline Garcia et al. [166] & $\begin{array}{l}\text { heat inactivated } \\
\text { autologous virus }\end{array}$ & autologous MDDC & IFN- $\alpha$ & $\mathrm{N}=18$ & HAART & Pulsing & S.C. & 4 doses every 6 weeks \\
\hline Ide et al. [167] & $\begin{array}{l}\text { synthetic peptides } \\
\text { with HLA-A*2402 } \\
\text { restriction of Gag, Pol, } \\
\text { Env }\end{array}$ & autologous MDDC & TNF- $\alpha$ & $\mathrm{N}=4$ & HAART & Pulsing & S.C. & 6 doses every 2 weeks \\
\hline Connolly et al. [168] & $\begin{array}{l}\text { synthetic peptides } \\
\text { with HLA-A*2402 } \\
\text { restriction of Gag, Pol, } \\
\text { Env }\end{array}$ & autologous MDDC & IL-1 $\beta$, IL-6, TNF- $\alpha$ & $\mathrm{N}=18$ & ART & Pulsing & I.V.\&S.C. & $\begin{array}{c}2 \text { doses with } 3 \text { week } \\
\text { interval }\end{array}$ \\
\hline Gandhi et al. [169] & $\begin{array}{c}\text { ALVAC-HIV-1 } \\
\text { vCP1452 } \\
\text { (Sanofi-Pasteur) }\end{array}$ & autologous MDDC & $\begin{array}{l}\text { Monocyte-conditioned } \\
\text { medium } \\
\text { containing IL-1 } \beta \text {, } \\
\text { IL- } 6 \text {, TNF- } \alpha, \text { PEG } 2\end{array}$ & $\mathrm{~N}=29$ & ART & $\begin{array}{l}\text { DCs infected with } \\
\text { live virus }\end{array}$ & S.C. & 3 doses at week $3,7,15$ \\
\hline Kloverpris et al. [170] & $\begin{array}{l}\text { synthetic peptides } \\
\text { with HLA-A*0201 } \\
\text { restriction of Gag, Vif, } \\
\text { Env, Vpu, Pol }\end{array}$ & autologous MDDC & $\begin{array}{c}\text { IL-1 } \beta, \text { IL-6, } \\
\text { TNF- } \alpha, \text { PEG2 }\end{array}$ & $\mathrm{N}=12$ & - & Pulsing & S.C. & 4 doses at week $0,2,4,8$ \\
\hline Routy et al. [154] & $\begin{array}{c}\text { RNA encoding Gag, } \\
\text { Rev, Vpr, Nef \& } \\
\text { CD40L } \\
\end{array}$ & autologous MDDC & $\begin{array}{l}\text { TNF- } \alpha, \text { IFN- } \gamma, \\
\text { PEG2 }\end{array}$ & $\mathrm{N}=10$ & ART & Electroporation & I.D. & $\begin{array}{c}4 \text { doses at week } \\
0,4,8,12\end{array}$ \\
\hline Gracia et al. [171] & $\begin{array}{l}\text { heat inactivated } \\
\text { autologous virus }\end{array}$ & autologous MDDC & IL-1 $\beta$, IL-6, TNF- $\alpha$ & $\mathrm{N}=24$ & - & Pulsing & S.C. & 3 doses every 2 weeks \\
\hline J.P.Routy et al. [172] & $\begin{array}{l}\text { RNA encoding Gag, } \\
\text { Rev, Vpr, Nef \& } \\
\text { CD40L }\end{array}$ & autologous MDDC & $\begin{array}{l}\text { TNF- } \alpha, \text { IFN- } \gamma, \\
\text { PEG2 }\end{array}$ & $\mathrm{N}=29$ & ART & Electroporation & S.C. & $\begin{array}{l}4 \text { doses at week } 0,4,8, \\
12 \text { and } 2 \text { booster doses } \\
\text { after ART interruption }\end{array}$ \\
\hline Allard et al. [173] & $\begin{array}{l}\text { RNA encoding Tat, } \\
\text { Rev, Nef }\end{array}$ & autologous MDDC & $\begin{array}{c}\text { GM-CSF, IL-4, } \\
\text { IL-1 } \beta, \text { IL-6, } \\
\text { TNF- } \alpha, \text { PEG2 }\end{array}$ & $\mathrm{N}=17$ & cART & Electroporation & S.C.\&I.D. & $\begin{array}{c}4 \text { doses at week } \\
0,4,8,12\end{array}$ \\
\hline Van Gulck et al. [174] & $\begin{array}{l}\text { RNA encoding Gag \& } \\
\text { chimeric Tat-Rev-Nef } \\
\text { protein }\end{array}$ & autologous MDDC & TNF- $\alpha$, PEG2 & $N=6$ & HAART & Electroporation & I.D.\&S.C. & $\begin{array}{c}4 \text { doses at week } \\
0,4,8,12\end{array}$ \\
\hline Garcia et al. [175] & $\begin{array}{l}\text { heat inactivated } \\
\text { autologous virus }\end{array}$ & autologous MDDC & $\begin{array}{l}\text { IL-1 } \beta, \text { IL-6, } \\
\text { TNF- } \alpha, \text { PEG2 }\end{array}$ & $\mathrm{N}=36$ & cART & Pulsing & S.C. or I.D. & $\begin{array}{c}3 \text { doses at week }-4,-2, \\
0 \text { \& week } 0,2,4 \\
\text { respectively }\end{array}$ \\
\hline
\end{tabular}


Table 1. Cont

\begin{tabular}{|c|c|c|c|c|c|c|c|c|}
\hline Author [Ref.] & HIV-1 Antigens & DC Type & DC Maturation & Subjects & Treatment & Loading Strategy & Route & Schedule \\
\hline Levy et al. [176] & $\begin{array}{l}\text { ANRS HIV LIPO5 } \\
\text { peptides: gag, pol, nef }\end{array}$ & autologous MDDC & LPS & $\mathrm{N}=19$ & HAART & Plusing & S.C. & $\begin{array}{c}4 \text { doses at week } \\
0,4,8,12\end{array}$ \\
\hline Tcherepanova et al. [177] & $\begin{array}{c}\text { RNA encoding Gag, } \\
\text { Rev, Vpr, Nef }\end{array}$ & autologous MDDC & Unkown & $\mathrm{N}=36$ & ART & Electroporation & Unknown & $\begin{array}{c}4 \text { doses at week } \\
0,4,8,12 \\
\end{array}$ \\
\hline Gandhi et al. [178] & $\begin{array}{l}\text { RNA encoding } \\
\text { Gag, Nef }\end{array}$ & autologous MDDC & $\begin{array}{c}\text { IL-1 } \beta, \text { IL-6, } \\
\text { TNF- } \alpha, \text { PEG2 }\end{array}$ & $\mathrm{N}=15$ & cART & Electroporation & I.D. & $\begin{array}{c}4 \text { doses at week } \\
0,2,6,10 \\
\end{array}$ \\
\hline Macatangay et al. [179] & $\begin{array}{c}\text { Autologous } \\
\text { inactivated } \\
\text { HIV-1-infected } \\
\text { apoptotic cells }\end{array}$ & autologous MDDC & $\begin{array}{c}\text { TNF- } \alpha, \text { IFN- } \alpha \\
\text { IFN- } \gamma, \text { IL- } 1 \beta, \\
\text { Poly(I:C) }\end{array}$ & $\mathrm{N}=10$ & ART & Pulsing & S.C. & $\begin{array}{c}3 \text { doses at week } 0,2,4, \& \\
\text { the } 4 \text { th dose at week } 24\end{array}$ \\
\hline
\end{tabular}

MDDC: Monocyte-derived dendritic cells; S.C.: subcutaneous injection; I.D.: Intradermal injection; I.V.: intravenous injection; HAART: Highly active antiretroviral therapy; ART: antiretroviral therapy; cART: combination antiretroviral therapy. 


\subsection{Potential Role of HIV-1 VLP in DC-Based HIV-1 Immunization}

Although encouraging results of DC-based HIV-1 immunotherapy clinical trials have been reported, a functional cure has not been achieved in any patient yet. There are several possibilities for improving the therapeutic effect of DC-based vaccines, including a novel form of HIV-1 antigen for DC pulsing, an improved DC pulsing method that enhances antigen presentation, different adjuvants that facilitate immune responses and optimization of clinical trial design, which will help in the data analysis and assessment of the efficacy of the vaccines. Regardless of the other factors that may affect the outcomes of the 17 clinical trials, the types of HIV-1 antigens utilized in these 17 clinical trials showed different degree of therapeutic effects, especially the decrease of viral load.

A previous clinical trial using DCs loaded with an AT-2-inactivated autologous virus showed a sustained viral load drop [165], and it was indicated that AT-2 inactivation preserves the conformational and functional integrity of the virion surface proteins, which may facilitate DC antigen presentation to induce potent CD4+ and CD8+ responses [180-182]. The HIV-1 VLP consists of viral capsid proteins that self-assemble into particulate structures and displays native functional Env spike on the surface, imitating the natural virus particles. Because HIV-1 VLP is not infectious, there is no need for inactivation. Based on the features of HIV-1 VLP, we would like to hypothesize that HIV-1 VLP may play a role as antigen for DC-based therapy and that the native Env trimers displayed on the VLP may also facilitate the development of broadly neutralizing antibody responses, which are beneficial for the control of viral load and clinical of progression of HIV infection.

In addition, the DCs loaded with HIV-1 VLP would be a supplementary boosting regimen for HIV-1 VLP vaccination. Administration of DCs loaded with HIV-1 antigen could be the most direct way of presenting antigens, and clinical trials of DC-based HIV-1 therapy have shown that T cell responses were successfully induced in HIV-1-infected patients with compromised immunity. Studies have demonstrated that a potent HIV-1-specific CD4+ T cell response is critical to induce a sustained and efficient HIV-specific CD8+ T response, which is important in controlling HIV replication by killing HIV-1-infected cells [183-187]. Signals provided by CD4+ T cells are also essential for memory $B$ cell differentiation and affinity maturation [188]. Thus, an effectively and properly primed CD4+ T cell response is fundamental for the development of protective anti-HIV-1 immune responses. DCs are potent professional APCs and are crucial for the induction of HIV-1-specific CD4+ T cell responses. Efficient antigen presentation benefits the priming of HIV-1 CD4+ T cell responses. Moreover, it is reported that HIV Gag-Pol-specific CD4+ T cells were capable of providing intrastructural help for Env-specific B cells and therefore facilitate antibody responses against HIV-1 [94]. Therefore, it is reasonable to assume that DC-based HIV immunization could be an effective way to induce immune responses to HIV-1 in healthy individuals. However, due to the complexity of DC-based immunization, we would like to propose DCs loaded with HIV-1 VLP as a supplementary boosting regimen for HIV-1 VLP vaccination.

\section{Conclusions}

HIV-1 VLP is a promising vaccine consisting of a viral capsid protein and native Env trimers presented on the surface, which could induce host immunological responses against HIV infection. Various modifications of VLPs can be adopted to improve the immunogenicity of HIV-1 VLPs. DC-based HIV therapeutic treatment has been explored as an alternative treatment of ART, which exhibited an excellent safety profile, and clinical trials demonstrated anti-HIV-1 immune responses induced by DC-based immunization, although a functional cure has not been achieved yet. Considering the advantages of HIV VLPs and DC-based HIV-1 treatment, we would like to suggest combining the two immunization strategies so that HIV-1 VLPs could be a potential antigen for DC-based HIV-1 therapeutic treatment, and this VLP-mediated DC-based vaccination could be an effective method for both mucosal and systematic immunization to boost the host immune responses against the HIV-1 pandemic. 
Acknowledgments: We thank X.Z.R. and X.Z. for helpful discussions. X.Y. holds a Manitoba Research Chair Award from the Manitoba Health Research Council (MHRC). This work was supported by Canadian Institute of Health Research (CIHR) (HBF-131553)/Canadian HIV Vaccine Initiative (CHVI) Bridge Funding (201309OCB), CIHR/MHRC RPP grant (RPA-132176), and National Natural Science Foundation of China (NNSFC, 81371863).

Author Contributions: Chongbo Zhao wrote the manuscript draft; Zhujun Ao and Xiaojian Yao provided conceptual advice and input to the manuscript, reviewed and revised the paper.

Conflicts of Interest: The authors declare no conflict of interest.

\section{References}

1. Barre-Sinoussi, F.; Chermann, J.C.; Rey, F.; Nugeyre, M.T.; Chamaret, S.; Gruest, J.; Dauguet, C.; Axler-Blin, C.; Vezinet-Brun, F.; Rouzioux, C.; et al. Isolation of a T-lymphotropic retrovirus from a patient at risk for acquired immune deficiency syndrome (AIDS). Science 1983, 220, 868-871. [CrossRef] [PubMed]

2. Gallo, R.C.; Sarin, P.S.; Gelmann, E.P.; Robert-Guroff, M.; Richardson, E.; Kalyanaraman, V.S.; Mann, D.; Sidhu, G.D.; Stahl, R.E.; Zolla-Pazner, S.; et al. Isolation of human T-cell leukemia virus in acquired immune deficiency syndrome (AIDS). Science 1983, 220, 865-867. [CrossRef] [PubMed]

3. Ezzell, C. Troublesome trials for AIDS vaccines. Nature 1987. [CrossRef]

4. Database of AIDS Vaccine Candidates in Clinical Trials. IAVI Report; International AIDS Vaccine Initiative (IAVI): New York, NY, USA, 2012.

5. Ross, A.L.; Brave, A.; Scarlatti, G.; Manrique, A.; Buonaguro, L. Progress towards development of an HIV vaccine: Report of the AIDS Vaccine 2009 Conference. Lancet Infect. Dis. 2010, 10, 305-316. [CrossRef]

6. Rerks-Ngarm, S.; Pitisuttithum, P.; Nitayaphan, S.; Kaewkungwal, J.; Chiu, J.; Paris, R.; Premsri, N.; Namwat, C.; de Souza, M.; Adams, E.; et al. Vaccination with ALVAC and AIDSVAX to prevent HIV-1 infection in Thailand. N. Engl. J. Med. 2009, 361, 2209-2220. [CrossRef] [PubMed]

7. Murphey-Corb, M. Live-attenuated HIV vaccines: How safe is safe enough? Nat. Med. 1997, 3, 17-18. [CrossRef] [PubMed]

8. Ruprecht, R.M. Live attenuated AIDS viruses as vaccines: Promise or peril? Immunol. Rev. 1999, 170, $135-149$. [CrossRef] [PubMed]

9. Salk, J. Prospects for the control of AIDS by immunizing seropositive individuals. Nature 1987, 327, 473-476. [CrossRef] [PubMed]

10. Poon, B.; Hsu, J.F.; Gudeman, V.; Chen, I.S.; Grovit-Ferbas, K. Formaldehyde-treated, heat-inactivated virions with increased human immunodeficiency virus type 1 env can be used to induce high-titer neutralizing antibody responses. J. Virol. 2005, 79, 10210-10217. [CrossRef] [PubMed]

11. Arthur, L.O.; Bess, J.W., Jr.; Urban, R.G.; Strominger, J.L.; Morton, W.R.; Mann, D.L.; Henderson, L.E.; Benveniste, R.E. Macaques immunized with HLA-DR are protected from challenge with simian immunodeficiency virus. J. Virol. 1995, 69, 3117-3124. [PubMed]

12. Stott, E.J. Anti-cell antibody in macaques. Nature 1991. [CrossRef] [PubMed]

13. Chan, W.L.; Rodgers, A.; Hancock, R.D.; Taffs, F.; Kitchin, P.; Farrar, G.; Liew, F.Y. Protection in simian immunodeficiency virus-vaccinated monkeys correlates with anti-HLA class I antibody response. J. Exp. Med. 1992, 176, 1203-1207. [CrossRef] [PubMed]

14. Lema, D.; Garcia, A.; De Sanctis, J.B. HIV vaccines: A brief overview. Scand. J. Immunol. 2014, 80, 1-11. [CrossRef] [PubMed]

15. Excler, J.L.; Robb, M.L.; Kim, J.H. HIV-1 vaccines: Challenges and new perspectives. Hum. Vaccines Immunother. 2014, 10, 1734-1746. [CrossRef] [PubMed]

16. Schiffner, T.; Sattentau, Q.J.; Dorrell, L. Development of prophylactic vaccines against HIV-1. Retrovirology 2013. [CrossRef] [PubMed]

17. O'Connell, R.J.; Kim, J.H.; Corey, L.; Michael, N.L. Human immunodeficiency virus vaccine trials. Cold Spring Harb. Perspect. Med. 2012. [CrossRef] [PubMed]

18. Bachmann, M.F.; Lutz, M.B.; Layton, G.T.; Harris, S.J.; Fehr, T.; Rescigno, M.; Ricciardi-Castagnoli, P. Dendritic cells process exogenous viral proteins and virus-like particles for class I presentation to CD8+ cytotoxic T lymphocytes. Eur. J. Immunol. 1996, 26, 2595-2600. [CrossRef] [PubMed]

19. Ruedl, C.; Storni, T.; Lechner, F.; Bachi, T.; Bachmann, M.F. Cross-presentation of virus-like particles by skin-derived CD8(-) dendritic cells: A dispensable role for TAP. Eur. J. Immunol. 2002, 32, 818-825. [CrossRef] 
20. Ruedl, C.; Schwarz, K.; Jegerlehner, A.; Storni, T.; Manolova, V.; Bachmann, M.F. Virus-like particles as carriers for T-cell epitopes: Limited inhibition of T-cell priming by carrier-specific antibodies. J. Virol. 2005, 79, 717-724. [CrossRef] [PubMed]

21. Noad, R.; Roy, P. Virus-like particles as immunogens. Trends Microbiol. 2003, 11, 438-444. [CrossRef]

22. Grgacic, E.V.; Anderson, D.A. Virus-like particles: Passport to immune recognition. Methods 2006, 40, 60-65. [CrossRef] [PubMed]

23. Ludwig, C.; Wagner, R. Virus-like particles-universal molecular toolboxes. Curr. Opin. Biotechnol. 2007, 18, 537-545. [CrossRef] [PubMed]

24. Naskalska, A.; Pyrc, K. Virus Like Particles as Immunogens and Universal Nanocarriers. Pol. J. Microbiol. 2015, 64, 3-13. [PubMed]

25. Kushnir, N.; Streatfield, S.J.; Yusibov, V. Virus-like particles as a highly efficient vaccine platform: Diversity of targets and production systems and advances in clinical development. Vaccine 2012, 31, 58-83. [CrossRef] [PubMed]

26. Reimann, J.; Schirmbeck, R. Alternative pathways for processing exogenous and endogenous antigens that can generate peptides for MHC class I-restricted presentation. Immunol. Rev. 1999, 172, 131-152. [CrossRef] [PubMed]

27. Bachmann, M.F.; Zinkernagel, R.M. Neutralizing antiviral B cell responses. Annu. Rev. Immunol. 1997, 15, 235-270. [CrossRef] [PubMed]

28. Buonaguro, L.; Tornesello, M.L.; Tagliamonte, M.; Gallo, R.C.; Wang, L.X.; Kamin-Lewis, R.; Abdelwahab, S.; Lewis, G.K.; Buonaguro, F.M. Baculovirus-derived human immunodeficiency virus type 1 virus-like particles activate dendritic cells and induce ex vivo T-cell responses. J. Virol. 2006, 80, 9134-9143. [CrossRef] [PubMed]

29. Buonaguro, L.; Visciano, M.L.; Tornesello, M.L.; Tagliamonte, M.; Biryahwaho, B.; Buonaguro, F.M. Induction of systemic and mucosal cross-clade neutralizing antibodies in BALB/c mice immunized with human immunodeficiency virus type 1 clade A virus-like particles administered by different routes of inoculation. J. Virol. 2005, 79, 7059-7067. [CrossRef] [PubMed]

30. Tsunetsugu-Yokota, Y.; Morikawa, Y.; Isogai, M.; Kawana-Tachikawa, A.; Odawara, T.; Nakamura, T.; Grassi, F.; Autran, B.; Iwamoto, A. Yeast-derived human immunodeficiency virus type 1 p55(gag) virus-like particles activate dendritic cells (DCs) and induce perforin expression in Gag-specific CD8(+) T cells by cross-presentation of DCs. J. Virol. 2003, 77, 10250-10259. [CrossRef] [PubMed]

31. Paliard, X.; Liu, Y.; Wagner, R.; Wolf, H.; Baenziger, J.; Walker, C.M. Priming of strong, broad, and long-lived HIV type 1 p55gag-specific CD8+ cytotoxic T cells after administration of a virus-like particle vaccine in rhesus macaques. AIDS Res. Hum. Retroviruses 2000, 16, 273-282. [CrossRef] [PubMed]

32. Lua, L.H.; Connors, N.K.; Sainsbury, F.; Chuan, Y.P.; Wibowo, N.; Middelberg, A.P. Bioengineering virus-like particles as vaccines. Biotechnol. Bioeng. 2014, 111, 425-440. [CrossRef] [PubMed]

33. Banchereau, J.; Steinman, R.M. Dendritic cells and the control of immunity. Nature 1998, 392, $245-252$. [CrossRef] [PubMed]

34. Larsson, M.; Fonteneau, J.F.; Bhardwaj, N. Cross-presentation of cell-associated antigens by dendritic cells. Curr. Top. Microbiol. Immunol. 2003, 276, 261-275. [PubMed]

35. Rossi, M.; Young, J.W. Human dendritic cells: Potent antigen-presenting cells at the crossroads of innate and adaptive immunity. J. Immunol. 2005, 175, 1373-1381. [CrossRef] [PubMed]

36. Patham, B.; Simmons, G.L.; Subramanya, S. Advances in dendritic cell-based vaccines for HIV. Curr. Med. Chem. 2011, 18, 3987-3994. [CrossRef] [PubMed]

37. Zhou, Y.; Zhang, Y.; Yao, Z.; Moorman, J.P.; Jia, Z. Dendritic cell-based immunity and vaccination against hepatitis C virus infection. Immunology 2012, 136, 385-396. [CrossRef] [PubMed]

38. Garcia, F.; Plana, M.; Climent, N.; Leon, A.; Gatell, J.M.; Gallart, T. Dendritic cell based vaccines for HIV infection: The way ahead. Hum. Vaccines Immunother. 2013, 9, 2445-2452. [CrossRef]

39. Miller, E.; Bhardwaj, N. Advances in dendritic cell immunotherapies for HIV-1 infection. Expert Opin. Biol. Ther. 2014, 14, 1545-1549. [CrossRef] [PubMed]

40. Anguille, S.; Smits, E.L.; Bryant, C.; Van Acker, H.H.; Goossens, H.; Lion, E.; Fromm, P.D.; Van Tendeloo, V.F.; Berneman, Z.N. Dendritic Cells as Pharmacological Tools for Cancer Immunotherapy. Pharmacol. Rev. 2015, 67, 731-753. [CrossRef] [PubMed]

41. Mac Keon, S.; Ruiz, M.S.; Gazzaniga, S.; Wainstok, R. Dendritic cell-based vaccination in cancer: Therapeutic implications emerging from murine models. Front. Immunol. 2015. [CrossRef] [PubMed] 
42. Hovden, A.O.; Appel, S. The first dendritic cell-based therapeutic cancer vaccine is approved by the FDA. Scand. J. Immunol. 2010. [CrossRef] [PubMed]

43. Mascola, J.R.; Montefiori, D.C. The role of antibodies in HIV vaccines. Annu. Rev. Immunol. 2010, $28,413-444$. [CrossRef] [PubMed]

44. Crooks, E.T.; Jiang, P.; Franti, M.; Wong, S.; Zwick, M.B.; Hoxie, J.A.; Robinson, J.E.; Moore, P.L.; Binley, J.M. Relationship of HIV-1 and SIV envelope glycoprotein trimer occupation and neutralization. Virology 2008, 377, 364-378. [CrossRef] [PubMed]

45. Barbas, C.F., 3rd; Bjorling, E.; Chiodi, F.; Dunlop, N.; Cababa, D.; Jones, T.M.; Zebedee, S.L.; Persson, M.A.; Nara, P.L.; Norrby, E.; et al. Recombinant human Fab fragments neutralize human type 1 immunodeficiency virus in vitro. Proc. Natl. Acad. Sci. USA 1992, 89, 9339-9343. [CrossRef] [PubMed]

46. Roben, P.; Moore, J.P.; Thali, M.; Sodroski, J.; Barbas, C.F., 3rd; Burton, D.R. Recognition properties of a panel of human recombinant Fab fragments to the CD4 binding site of gp120 that show differing abilities to neutralize human immunodeficiency virus type 1. J. Virol. 1994, 68, 4821-4828. [PubMed]

47. Burton, D.R.; Pyati, J.; Koduri, R.; Sharp, S.J.; Thornton, G.B.; Parren, P.W.; Sawyer, L.S.; Hendry, R.M.; Dunlop, N.; Nara, P.L.; et al. Efficient neutralization of primary isolates of HIV-1 by a recombinant human monoclonal antibody. Science 1994, 266, 1024-1027. [CrossRef] [PubMed]

48. Sanders, R.W.; Venturi, M.; Schiffner, L.; Kalyanaraman, R.; Katinger, H.; Lloyd, K.O.; Kwong, P.D.; Moore, J.P. The mannose-dependent epitope for neutralizing antibody $2 \mathrm{G} 12$ on human immunodeficiency virus type 1 glycoprotein gp120. J. Virol. 2002, 76, 7293-7305. [CrossRef] [PubMed]

49. Muster, T.; Steindl, F.; Purtscher, M.; Trkola, A.; Klima, A.; Himmler, G.; Ruker, F.; Katinger, H. A conserved neutralizing epitope on gp41 of human immunodeficiency virus type 1. J. Virol. 1993, 67, 6642-6647. [PubMed]

50. Stiegler, G.; Kunert, R.; Purtscher, M.; Wolbank, S.; Voglauer, R.; Steindl, F.; Katinger, H. A potent cross-clade neutralizing human monoclonal antibody against a novel epitope on gp41 of human immunodeficiency virus type 1. AIDS Res. Hum. Retroviruses 2001, 17, 1757-1765. [CrossRef] [PubMed]

51. Zwick, M.B.; Labrijn, A.F.; Wang, M.; Spenlehauer, C.; Saphire, E.O.; Binley, J.M.; Moore, J.P.; Stiegler, G.; Katinger, H.; Burton, D.R.; et al. Broadly neutralizing antibodies targeted to the membrane-proximal external region of human immunodeficiency virus type 1 glycoprotein gp41. J. Virol. 2001, 75, 10892-10905. [CrossRef] [PubMed]

52. Wu, X.; Yang, Z.Y.; Li, Y.; Hogerkorp, C.M.; Schief, W.R.; Seaman, M.S.; Zhou, T.; Schmidt, S.D.; Wu, L.; $\mathrm{Xu}, \mathrm{L} . ;$ et al. Rational design of envelope identifies broadly neutralizing human monoclonal antibodies to HIV-1. Science 2010, 329, 856-861. [CrossRef] [PubMed]

53. Corti, D.; Langedijk, J.P.; Hinz, A.; Seaman, M.S.; Vanzetta, F.; Fernandez-Rodriguez, B.M.; Silacci, C.; Pinna, D.; Jarrossay, D.; Balla-Jhagjhoorsingh, S.; et al. Analysis of memory B cell responses and isolation of novel monoclonal antibodies with neutralizing breadth from HIV-1-infected individuals. PLoS ONE 2010, 5, e8805. [CrossRef] [PubMed]

54. Walker, L.M.; Phogat, S.K.; Chan-Hui, P.Y.; Wagner, D.; Phung, P.; Goss, J.L.; Wrin, T.; Simek, M.D.; Fling, S.; Mitcham, J.L.; et al. Broad and potent neutralizing antibodies from an African donor reveal a new HIV-1 vaccine target. Science 2009, 326, 285-289. [CrossRef] [PubMed]

55. Gorny, M.K.; Williams, C.; Volsky, B.; Revesz, K.; Wang, X.H.; Burda, S.; Kimura, T.; Konings, F.A.; Nadas, A.; Anyangwe, C.A.; et al. Cross-clade neutralizing activity of human anti-V3 monoclonal antibodies derived from the cells of individuals infected with non-B clades of human immunodeficiency virus type 1. J. Virol. 2006, 80, 6865-6872. [CrossRef] [PubMed]

56. Bell, C.H.; Pantophlet, R.; Schiefner, A.; Cavacini, L.A.; Stanfield, R.L.; Burton, D.R.; Wilson, I.A. Structure of antibody F425-B4e8 in complex with a V3 peptide reveals a new binding mode for HIV-1 neutralization. J. Mol. Biol. 2008, 375, 969-978. [CrossRef] [PubMed]

57. Pantophlet, R.; Wrin, T.; Cavacini, L.A.; Robinson, J.E.; Burton, D.R. Neutralizing activity of antibodies to the V3 loop region of HIV-1 gp120 relative to their epitope fine specificity. Virology 2008, 381, 251-260. [CrossRef] [PubMed]

58. Blattner, C.; Lee, J.H.; Sliepen, K.; Derking, R.; Falkowska, E.; de la Pena, A.T.; Cupo, A.; Julien, J.P.; van Gils, M.; Lee, P.S.; et al. Structural delineation of a quaternary, cleavage-dependent epitope at the gp41-gp120 interface on intact HIV-1 Env trimers. Immunity 2014, 40, 669-680. [CrossRef] [PubMed] 
59. Falkowska, E.; Le, K.M.; Ramos, A.; Doores, K.J.; Lee, J.H.; Blattner, C.; Ramirez, A.; Derking, R.; van Gils, M.J.; Liang, C.H.; et al. Broadly neutralizing HIV antibodies define a glycan-dependent epitope on the prefusion conformation of gp41 on cleaved envelope trimers. Immunity 2014, 40, 657-668. [CrossRef] [PubMed]

60. Mouquet, H.; Scharf, L.; Euler, Z.; Liu, Y.; Eden, C.; Scheid, J.F.; Halper-Stromberg, A.; Gnanapragasam, P.N.; Spencer, D.I.; Seaman, M.S.; et al. Complex-type N-glycan recognition by potent broadly neutralizing HIV antibodies. Proc. Natl. Acad. Sci. USA 2012, 109, E3268-E3277. [CrossRef] [PubMed]

61. Julien, J.P.; Sok, D.; Khayat, R.; Lee, J.H.; Doores, K.J.; Walker, L.M.; Ramos, A.; Diwanji, D.C.; Pejchal, R.; Cupo, A.; et al. Broadly neutralizing antibody PGT121 allosterically modulates CD4 binding via recognition of the HIV-1 gp120 V3 base and multiple surrounding glycans. PLoS Pathog. 2013, 9, e1003342. [CrossRef] [PubMed]

62. Klein, F.; Halper-Stromberg, A.; Horwitz, J.A.; Gruell, H.; Scheid, J.F.; Bournazos, S.; Mouquet, H.; Spatz, L.A.; Diskin, R.; Abadir, A.; et al. HIV therapy by a combination of broadly neutralizing antibodies in humanized mice. Nature 2012, 492, 118-122. [CrossRef] [PubMed]

63. Klein, F.; Diskin, R.; Scheid, J.F.; Gaebler, C.; Mouquet, H.; Georgiev, I.S.; Pancera, M.; Zhou, T.; Incesu, R.B.; $\mathrm{Fu}$, B.Z.; et al. Somatic mutations of the immunoglobulin framework are generally required for broad and potent HIV-1 neutralization. Cell 2013, 153, 126-138. [CrossRef] [PubMed]

64. Wei, X.; Decker, J.M.; Wang, S.; Hui, H.; Kappes, J.C.; Wu, X.; Salazar-Gonzalez, J.F.; Salazar, M.G.; Kilby, J.M.; Saag, M.S.; et al. Antibody neutralization and escape by HIV-1. Nature 2003, 422, 307-312. [CrossRef] [PubMed]

65. Sagar, M.; Wu, X.; Lee, S.; Overbaugh, J. Human immunodeficiency virus type 1 V1-V2 envelope loop sequences expand and add glycosylation sites over the course of infection, and these modifications affect antibody neutralization sensitivity. J. Virol. 2006, 80, 9586-9598. [CrossRef] [PubMed]

66. Van Gils, M.J.; Bunnik, E.M.; Boeser-Nunnink, B.D.; Burger, J.A.; Terlouw-Klein, M.; Verwer, N.; Schuitemaker, H. Longer V1V2 region with increased number of potential N-linked glycosylation sites in the HIV-1 envelope glycoprotein protects against HIV-specific neutralizing antibodies. J. Virol. 2011, 85, 6986-6995. [CrossRef] [PubMed]

67. Pancera, M.; Zhou, T.; Druz, A.; Georgiev, I.S.; Soto, C.; Gorman, J.; Huang, J.; Acharya, P.; Chuang, G.Y.; Ofek, G.; et al. Structure and immune recognition of trimeric pre-fusion HIV-1 Env. Nature 2014, 514, 455-461. [CrossRef] [PubMed]

68. Frey, G.; Peng, H.; Rits-Volloch, S.; Morelli, M.; Cheng, Y.; Chen, B. A fusion-intermediate state of HIV-1 gp41 targeted by broadly neutralizing antibodies. Proc. Natl. Acad. Sci. USA 2008, 105, 3739-3744. [CrossRef] [PubMed]

69. Montero, M.; van Houten, N.E.; Wang, X.; Scott, J.K. The membrane-proximal external region of the human immunodeficiency virus type 1 envelope: Dominant site of antibody neutralization and target for vaccine design. Microbiol. Mol. Biol. Rev. 2008, 72, 54-84. [CrossRef] [PubMed]

70. Burton, D.R.; Mascola, J.R. Antibody responses to envelope glycoproteins in HIV-1 infection. Nat. Immunol. 2015, 16, 571-576. [CrossRef] [PubMed]

71. Klein, J.S.; Bjorkman, P.J. Few and far between: How HIV may be evading antibody avidity. PLoS Pathog. 2010, 6, e1000908. [CrossRef] [PubMed]

72. Liu, J.; Bartesaghi, A.; Borgnia, M.J.; Sapiro, G.; Subramaniam, S. Molecular architecture of native HIV-1 gp120 trimers. Nature 2008, 455, 109-113. [CrossRef] [PubMed]

73. Mouquet, H.; Scheid, J.F.; Zoller, M.J.; Krogsgaard, M.; Ott, R.G.; Shukair, S.; Artyomov, M.N.; Pietzsch, J.; Connors, M.; Pereyra, F.; et al. Polyreactivity increases the apparent affinity of anti-HIV antibodies by heteroligation. Nature 2010, 467, 591-595. [CrossRef] [PubMed]

74. Chertova, E.; Bess, J.W., Jr.; Crise, B.J.; Sowder, I.R.; Schaden, T.M.; Hilburn, J.M.; Hoxie, J.A.; Benveniste, R.E.; Lifson, J.D.; Henderson, L.E.; et al. Envelope glycoprotein incorporation, not shedding of surface envelope glycoprotein (gp120/SU), Is the primary determinant of SU content of purified human immunodeficiency virus type 1 and simian immunodeficiency virus. J. Virol. 2002, 76, 5315-5325. [CrossRef] [PubMed]

75. Zhu, P.; Liu, J.; Bess, J., Jr.; Chertova, E.; Lifson, J.D.; Grise, H.; Ofek, G.A.; Taylor, K.A.; Roux, K.H. Distribution and three-dimensional structure of AIDS virus envelope spikes. Nature 2006, 441, 847-852. [CrossRef] [PubMed] 
76. Crooks, E.T.; Tong, T.; Chakrabarti, B.; Narayan, K.; Georgiev, I.S.; Menis, S.; Huang, X.; Kulp, D.; Osawa, K.; Muranaka, J.; et al. Vaccine-Elicited Tier 2 HIV-1 Neutralizing Antibodies Bind to Quaternary Epitopes Involving Glycan-Deficient Patches Proximal to the CD4 Binding Site. PLoS Pathog. 2015, 11, e1004932. [CrossRef] [PubMed]

77. McGuire, A.T.; Hoot, S.; Dreyer, A.M.; Lippy, A.; Stuart, A.; Cohen, K.W.; Jardine, J.; Menis, S.; Scheid, J.F.; West, A.P.; et al. Engineering HIV envelope protein to activate germline B cell receptors of broadly neutralizing anti-CD4 binding site antibodies. J. Exp. Med. 2013, 210, 655-663. [CrossRef] [PubMed]

78. Hoot, S.; McGuire, A.T.; Cohen, K.W.; Strong, R.K.; Hangartner, L.; Klein, F.; Diskin, R.; Scheid, J.F.; Sather, D.N.; Burton, D.R.; et al. Recombinant HIV envelope proteins fail to engage germline versions of anti-CD4bs bNAbs. PLoS Pathog. 2013, 9, e1003106.

79. Zhai, Y.; Zhong, Z.; Zariffard, M.; Spear, G.T.; Qiao, L. Bovine papillomavirus-like particles presenting conserved epitopes from membrane-proximal external region of HIV-1 gp41 induced mucosal and systemic antibodies. Vaccine 2013, 31, 5422-5429. [CrossRef] [PubMed]

80. Pastori, C.; Tudor, D.; Diomede, L.; Drillet, A.S.; Jegerlehner, A.; Rohn, T.A.; Bomsel, M.; Lopalco, L. Virus like particle based strategy to elicit HIV-protective antibodies to the alpha-helic regions of gp41. Virology 2012, 431, 1-11. [CrossRef] [PubMed]

81. Bachmann, M.F.; Rohrer, U.H.; Kundig, T.M.; Burki, K.; Hengartner, H.; Zinkernagel, R.M. The influence of antigen organization on B cell responsiveness. Science 1993, 262, 1448-1451. [CrossRef] [PubMed]

82. Tong, T.; Crooks, E.T.; Osawa, K.; Binley, J.M. HIV-1 virus-like particles bearing pure env trimers expose neutralizing epitopes but occlude nonneutralizing epitopes. J. Virol. 2012, 86, 3574-3587. [CrossRef] [PubMed]

83. Visciano, M.L.; Diomede, L.; Tagliamonte, M.; Tornesello, M.L.; Asti, V.; Bomsel, M.; Buonaguro, F.M.; Lopalco, L.; Buonaguro, L. Generation of HIV-1 Virus-Like Particles expressing different HIV-1 glycoproteins. Vaccine 2011, 29, 4903-4912. [CrossRef] [PubMed]

84. Buonaguro, L.; Buonaguro, F.M.; Tornesello, M.L.; Mantas, D.; Beth-Giraldo, E.; Wagner, R.; Michelson, S.; Prevost, M.C.; Wolf, H.; Giraldo, G. High efficient production of Pr55(gag) virus-like particles expressing multiple HIV-1 epitopes, including a gp120 protein derived from an Ugandan HIV-1 isolate of subtype A. Antivir. Res. 2001, 49, 35-47. [CrossRef]

85. Deml, L.; Speth, C.; Dierich, M.P.; Wolf, H.; Wagner, R. Recombinant HIV-1 Pr55gag virus-like particles: Potent stimulators of innate and acquired immune responses. Mol. Immunol. 2005, 42, 259-277. [CrossRef] [PubMed]

86. Rovinski, B.; Rodrigues, L.; Cao, S.X.; Yao, F.L.; McGuinness, U.; Sia, C.; Cates, G.; Zolla-Pazner, S.; Karwowska, S.; Matthews, T.J.; et al. Induction of HIV type 1 neutralizing and env-CD4 blocking antibodies by immunization with genetically engineered HIV type 1-like particles containing unprocessed gp160 glycoproteins. AIDS Res. Hum. Retroviruses 1995, 11, 1187-1195. [CrossRef] [PubMed]

87. Sakuragi, S.; Goto, T.; Sano, K.; Morikawa, Y. HIV type 1 Gag virus-like particle budding from spheroplasts of Saccharomyces cerevisiae. Proc. Natl. Acad. Sci. USA 2002, 99, 7956-7961. [CrossRef] [PubMed]

88. Buonaguro, L.; Racioppi, L.; Tornesello, M.L.; Arra, C.; Visciano, M.L.; Biryahwaho, B.; Sempala, S.D.; Giraldo, G.; Buonaguro, F.M. Induction of neutralizing antibodies and cytotoxic T lymphocytes in Balb/c mice immunized with virus-like particles presenting a gp120 molecule from a HIV-1 isolate of clade A. Antivir. Res. 2002, 54, 189-201. [CrossRef]

89. Chang, M.O.; Suzuki, T.; Suzuki, H.; Takaku, H. HIV-1 Gag-virus-like particles induce natural killer cell immune responses via activation and maturation of dendritic cells. J. Innate Immun. 2012, 4, 187-200. [CrossRef] [PubMed]

90. Chang, M.O.; Suzuki, T.; Yamamoto, N.; Watanabe, M.; Takaku, H. HIV-1 Gag-virus-like particles inhibit HIV-1 replication in dendritic cells and T cells through IFN-alpha-dependent upregulation of APOBEC3G and 3F. J. Innate Immun. 2012, 4, 579-590. [CrossRef] [PubMed]

91. Casimiro, D.R.; Wang, F.; Schleif, W.A.; Liang, X.; Zhang, Z.Q.; Tobery, T.W.; Davies, M.E.; McDermott, A.B.; O'Connor, D.H.; Fridman, A.; et al. Attenuation of simian immunodeficiency virus SIVmac239 infection by prophylactic immunization with dna and recombinant adenoviral vaccine vectors expressing Gag. J. Virol. 2005, 79, 15547-15555. [CrossRef] [PubMed] 
92. Liu, J.; O’Brien, K.L.; Lynch, D.M.; Simmons, N.L.; La Porte, A.; Riggs, A.M.; Abbink, P.; Coffey, R.T.; Grandpre, L.E.; Seaman, M.S.; et al. Immune control of an SIV challenge by a T-cell-based vaccine in rhesus monkeys. Nature 2009, 457, 87-91. [CrossRef] [PubMed]

93. Liang, X.; Casimiro, D.R.; Schleif, W.A.; Wang, F.; Davies, M.E.; Zhang, Z.Q.; Fu, T.M.; Finnefrock, A.C.; Handt, L.; Citron, M.P.; et al. Vectored Gag and Env but not Tat show efficacy against simian-human immunodeficiency virus 89.6P challenge in Mamu-A*01-negative rhesus monkeys. J. Virol. 2005, 79, 12321-12331. [CrossRef] [PubMed]

94. Nabi, G.; Genannt Bonsmann, M.S.; Tenbusch, M.; Gardt, O.; Barouch, D.H.; Temchura, V.; Uberla, K. GagPol-specific CD4(+) T-cells increase the antibody response to Env by intrastructural help. Retrovirology 2013. [CrossRef] [PubMed]

95. Perdiguero, B.; Gomez, C.E.; Cepeda, V.; Sanchez-Sampedro, L.; Garcia-Arriaza, J.; Mejias-Perez, E.; Jimenez, V.; Sanchez, C.; Sorzano, C.O.; Oliveros, J.C.; et al. Virological and immunological characterization of novel NYVAC-based HIV / AIDS vaccine candidates expressing clade C trimeric soluble gp140(ZM96) and Gag(ZM96)-Pol-Nef(CN54) as virus-like particles. J. Virol. 2015, 89, 970-988. [CrossRef] [PubMed]

96. Kanagavelu, S.K.; Snarsky, V.; Termini, J.M.; Gupta, S.; Barzee, S.; Wright, J.A.; Khan, W.N.; Kornbluth, R.S.; Stone, G.W. Soluble multi-trimeric TNF superfamily ligand adjuvants enhance immune responses to a HIV-1 Gag DNA vaccine. Vaccine 2012, 30, 691-702. [CrossRef] [PubMed]

97. Castaldello, A.; Sgarbanti, M.; Marsili, G.; Brocca-Cofano, E.; Remoli, A.L.; Caputo, A.; Battistini, A. Interferon regulatory factor- 1 acts as a powerful adjuvant in tat DNA based vaccination. J. Cell. Physiol. 2010, 224, 702-709. [CrossRef] [PubMed]

98. Xu, R.; Megati, S.; Roopchand, V.; Luckay, A.; Masood, A.; Garcia-Hand, D.; Rosati, M.; Weiner, D.B.; Felber, B.K.; Pavlakis, G.N.; et al. Comparative ability of various plasmid-based cytokines and chemokines to adjuvant the activity of HIV plasmid DNA vaccines. Vaccine 2008, 26, 4819-4829. [CrossRef] [PubMed]

99. Calarota, S.A.; Dai, A.; Trocio, J.N.; Weiner, D.B.; Lori, F.; Lisziewicz, J. IL-15 as memory T-cell adjuvant for topical HIV-1 DermaVir vaccine. Vaccine 2008, 26, 5188-5195. [CrossRef] [PubMed]

100. Robinson, H.L.; Montefiori, D.C.; Villinger, F.; Robinson, J.E.; Sharma, S.; Wyatt, L.S.; Earl, P.L.; McClure, H.M.; Moss, B.; Amara, R.R. Studies on GM-CSF DNA as an adjuvant for neutralizing Ab elicited by a DNA/MVA immunodeficiency virus vaccine. Virology 2006, 352, 285-294. [CrossRef] [PubMed]

101. Lai, L.; Kwa, S.; Kozlowski, P.A.; Montefiori, D.C.; Ferrari, G.; Johnson, W.E.; Hirsch, V.; Villinger, F.; Chennareddi, L.; Earl, P.L.; et al. Prevention of infection by a granulocyte-macrophage colony-stimulating factor co-expressing DNA/modified vaccinia Ankara simian immunodeficiency virus vaccine. J. Infect. Dis. 2011, 204, 164-173. [CrossRef] [PubMed]

102. Romagnani, S. Biology of human TH1 and TH2 cells. J. Clin. Immunol. 1995, 15, 121-129. [CrossRef] [PubMed]

103. Gluckman, J.C.; Canque, B.; Chapuis, F.; Rosenzwajg, M. In vitro generation of human dendritic cells and cell therapy. Cytokines Cell. Mol. Ther. 1997, 3, 187-196. [PubMed]

104. Hercus, T.R.; Thomas, D.; Guthridge, M.A.; Ekert, P.G.; King-Scott, J.; Parker, M.W.; Lopez, A.F. The granulocyte-macrophage colony-stimulating factor receptor: Linking its structure to cell signaling and its role in disease. Blood 2009, 114, 1289-1298. [CrossRef] [PubMed]

105. Rogers, W.O.; Weiss, W.R.; Kumar, A.; Aguiar, J.C.; Tine, J.A.; Gwadz, R.; Harre, J.G.; Gowda, K.; Rathore, D.; Kumar, S.; et al. Protection of rhesus macaques against lethal Plasmodium knowlesi malaria by a heterologous DNA priming and poxvirus boosting immunization regimen. Infect. Immun. 2002, 70, 4329-4335. [CrossRef] [PubMed]

106. Deng, J.; Yuan, S.; Pennati, A.; Murphy, J.; Wu, J.H.; Lawson, D.; Galipeau, J. Engineered fusokine GIFT4 licenses the ability of B cells to trigger a tumoricidal T-cell response. Cancer Res. 2014, 74, 4133-4144. [CrossRef] [PubMed]

107. Feng, H.; Zhang, H.; Deng, J.; Wang, L.; He, Y.; Wang, S.; Seyedtabaei, R.; Wang, Q.; Liu, L.; Galipeau, J.; et al. Incorporation of a GPI-anchored engineered cytokine as a molecular adjuvant enhances the immunogenicity of HIV VLPs. Sci. Rep. 2015. [CrossRef] [PubMed]

108. Vassilieva, E.V.; Wang, B.Z.; Vzorov, A.N.; Wang, L.; Wang, Y.C.; Bozja, J.; Xu, R.; Compans, R.W. Enhanced mucosal immune responses to HIV virus-like particles containing a membrane-anchored adjuvant. MBio 2011. [CrossRef] [PubMed] 
109. Smith, K.D.; Andersen-Nissen, E.; Hayashi, F.; Strobe, K.; Bergman, M.A.; Barrett, S.L.; Cookson, B.T.; Aderem, A. Toll-like receptor 5 recognizes a conserved site on flagellin required for protofilament formation and bacterial motility. Nat. Immunol. 2003, 4, 1247-1253. [CrossRef] [PubMed]

110. Mizel, S.B.; Honko, A.N.; Moors, M.A.; Smith, P.S.; West, A.P. Induction of macrophage nitric oxide production by Gram-negative flagellin involves signaling via heteromeric Toll-like receptor 5/Toll-like receptor 4 complexes. J. Immunol. 2003, 170, 6217-6223. [CrossRef] [PubMed]

111. Cuadros, C.; Lopez-Hernandez, F.J.; Dominguez, A.L.; McClelland, M.; Lustgarten, J. Flagellin fusion proteins as adjuvants or vaccines induce specific immune responses. Infect. Immun. 2004, 72, 2810-2816. [CrossRef] [PubMed]

112. Honko, A.N.; Sriranganathan, N.; Lees, C.J.; Mizel, S.B. Flagellin is an effective adjuvant for immunization against lethal respiratory challenge with Yersinia pestis. Infect. Immun. 2006, 74, 1113-1120. [CrossRef] [PubMed]

113. Shortman, K.; Lahoud, M.H.; Caminschi, I. Improving vaccines by targeting antigens to dendritic cells. Exp. Mol. Med. 2009, 41, 61-66. [CrossRef] [PubMed]

114. Zhang, R.; Zhang, S.; Li, M.; Chen, C.; Yao, Q. Incorporation of CD40 ligand into SHIV virus-like particles (VLP) enhances SHIV-VLP-induced dendritic cell activation and boosts immune responses against HIV. Vaccine 2010, 28, 5114-5127. [CrossRef] [PubMed]

115. Franco, D.; Liu, W.; Gardiner, D.F.; Hahn, B.H.; Ho, D.D. CD40L-containing virus-like particle as a candidate HIV-1 vaccine targeting dendritic cells. J. Acquir. Immune Defic. Syndr. 2011, 56, 393-400. [CrossRef] [PubMed]

116. Hedden, S.L.; Whitaker, D.; Floyd, L.; Latimer, W.W. Gender differences in the prevalence and behavioral risk factors of HIV in South African drug users. AIDS Behav. 2009, 13, 288-296. [CrossRef] [PubMed]

117. Letvin, N.L. Strategies for an HIV vaccine. J. Clin. Investig. 2002, 110, 15-20. [CrossRef] [PubMed]

118. Ambrose, Z.; Larsen, K.; Thompson, J.; Stevens, Y.; Finn, E.; Hu, S.L.; Bosch, M.L. Evidence for early local viral replication and local production of antiviral immunity upon mucosal simian-human immunodeficiency virus SHIV(89.6) infection in Macaca nemestrina. J. Virol. 2001, 75, 8589-8596. [CrossRef] [PubMed]

119. Haase, A.T. Targeting early infection to prevent HIV-1 mucosal transmission. Nature 2010, 464, $217-223$. [CrossRef] [PubMed]

120. Devito, C.; Broliden, K.; Kaul, R.; Svensson, L.; Johansen, K.; Kiama, P.; Kimani, J.; Lopalco, L.; Piconi, S.; Bwayo, J.J.; et al. Mucosal and plasma IgA from HIV-1-exposed uninfected individuals inhibit HIV-1 transcytosis across human epithelial cells. J. Immunol. 2000, 165, 5170-5176. [CrossRef] [PubMed]

121. Tudor, D.; Derrien, M.; Diomede, L.; Drillet, A.S.; Houimel, M.; Moog, C.; Reynes, J.M.; Lopalco, L.; Bomsel, M. HIV-1 gp41-specific monoclonal mucosal IgAs derived from highly exposed but IgG-seronegative individuals block HIV-1 epithelial transcytosis and neutralize CD4(+) cell infection: An IgA gene and functional analysis. Mucosal Immunol. 2009, 2, 412-426. [CrossRef] [PubMed]

122. Tumpey, T.M.; Renshaw, M.; Clements, J.D.; Katz, J.M. Mucosal delivery of inactivated influenza vaccine induces B-cell-dependent heterosubtypic cross-protection against lethal influenza A H5N1 virus infection. J. Virol. 2001, 75, 5141-5150. [CrossRef] [PubMed]

123. Stephenson, I.; Zambon, M.C.; Rudin, A.; Colegate, A.; Podda, A.; Bugarini, R.; Del Giudice, G.; Minutello, A.; Bonnington, S.; Holmgren, J.; et al. Phase I evaluation of intranasal trivalent inactivated influenza vaccine with nontoxigenic Escherichia coli enterotoxin and novel biovector as mucosal adjuvants, using adult volunteers. J. Virol. 2006, 80, 4962-4970. [CrossRef] [PubMed]

124. Asahi-Ozaki, Y.; Itamura, S.; Ichinohe, T.; Strong, P.; Tamura, S.; Takahashi, H.; Sawa, H.; Moriyama, M.; Tashiro, M.; Sata, T.; et al. Intranasal administration of adjuvant-combined recombinant influenza virus HA vaccine protects mice from the lethal H5N1 virus infection. Microbes Infect. 2006, 8, 2706-2714. [CrossRef] [PubMed]

125. Prabakaran, M.; Velumani, S.; He, F.; Karuppannan, A.K.; Geng, G.Y.; Yin, L.K.; Kwang, J. Protective immunity against influenza $\mathrm{H} 5 \mathrm{~N} 1$ virus challenge in mice by intranasal co-administration of baculovirus surface-displayed HA and recombinant CTB as an adjuvant. Virology 2008, 380, 412-420. [CrossRef] [PubMed]

126. Ichinohe, T.; Ainai, A.; Ami, Y.; Nagata, N.; Iwata, N.; Kawaguchi, A.; Suzaki, Y.; Odagiri, T.; Tashiro, M.; Takahashi, H.; et al. Intranasal administration of adjuvant-combined vaccine protects monkeys from challenge with the highly pathogenic influenza A H5N1 virus. J. Med. Virol. 2010, 82, 1754-1761. [CrossRef] [PubMed] 
127. Wang, B.Z.; Xu, R.; Quan, F.S.; Kang, S.M.; Wang, L.; Compans, R.W. Intranasal immunization with influenza VLPs incorporating membrane-anchored flagellin induces strong heterosubtypic protection. PLoS ONE 2010, 5, e13972. [CrossRef] [PubMed]

128. Boyaka, P.N.; McGhee, J.R. Cytokines as adjuvants for the induction of mucosal immunity. Adv. Drug Deliv. Rev. 2001, 51, 71-79. [CrossRef]

129. Yao, Q.; Vuong, V.; Li, M.; Compans, R.W. Intranasal immunization with SIV virus-like particles (VLPs) elicits systemic and mucosal immunity. Vaccine 2002, 20, 2537-2545. [CrossRef]

130. Buonaguro, L.; Devito, C.; Tornesello, M.L.; Schroder, U.; Wahren, B.; Hinkula, J.; Buonaguro, F.M. DNA-VLP prime-boost intra-nasal immunization induces cellular and humoral anti-HIV-1 systemic and mucosal immunity with cross-clade neutralizing activity. Vaccine 2007, 25, 5968-5977. [CrossRef] [PubMed]

131. Perrone, L.A.; Ahmad, A.; Veguilla, V.; Lu, X.; Smith, G.; Katz, J.M.; Pushko, P.; Tumpey, T.M. Intranasal vaccination with 1918 influenza virus-like particles protects mice and ferrets from lethal 1918 and H5N1 influenza virus challenge. J. Virol. 2009, 83, 5726-5734. [CrossRef] [PubMed]

132. Buonaguro, L.; Tornesello, M.L.; Buonaguro, F.M. Virus-like particles as particulate vaccines. Curr. HIV Res. 2010, 8, 299-309. [CrossRef] [PubMed]

133. El-Kamary, S.S.; Pasetti, M.F.; Mendelman, P.M.; Frey, S.E.; Bernstein, D.I.; Treanor, J.J.; Ferreira, J.; Chen, W.H.; Sublett, R.; Richardson, C.; et al. Adjuvanted intranasal Norwalk virus-like particle vaccine elicits antibodies and antibody-secreting cells that express homing receptors for mucosal and peripheral lymphoid tissues. J. Infect. Dis. 2010, 202, 1649-1658. [CrossRef] [PubMed]

134. Buonaguro, L.; Tagliamonte, M.; Tornesello, M.L.; Buonaguro, F.M. Developments in virus-like particle-based vaccines for infectious diseases and cancer. Expert Rev. Vaccines 2011, 10, 1569-1583. [CrossRef] [PubMed]

135. Velasquez, L.S.; Shira, S.; Berta, A.N.; Kilbourne, J.; Medi, B.M.; Tizard, I.; Ni, Y.; Arntzen, C.J.; Herbst-Kralovetz, M.M. Intranasal delivery of Norwalk virus-like particles formulated in an in situ gelling, dry powder vaccine. Vaccine 2011, 29, 5221-5231. [CrossRef] [PubMed]

136. Buonaguro, L.; Tagliamonte, M.; Visciano, M.L.; Andersen, H.; Lewis, M.; Pal, R.; Tornesello, M.L.; Schroeder, U.; Hinkula, J.; Wahren, B.; et al. Immunogenicity of HIV virus-like particles in rhesus macaques by intranasal administration. Clin. Vaccine Immunol. 2012, 19, 970-973. [CrossRef] [PubMed]

137. Liu, X.S.; Abdul-Jabbar, I.; Qi, Y.M.; Frazer, I.H.; Zhou, J. Mucosal immunisation with papillomavirus virus-like particles elicits systemic and mucosal immunity in mice. Virology 1998, 252, 39-45. [CrossRef] [PubMed]

138. Chackerian, B.; Lowy, D.R.; Schiller, J.T. Induction of autoantibodies to mouse CCR5 with recombinant papillomavirus particles. Proc. Natl. Acad. Sci. USA 1999, 96, 2373-2378. [CrossRef] [PubMed]

139. Shi, W.; Liu, J.; Huang, Y.; Qiao, L. Papillomavirus pseudovirus: A novel vaccine to induce mucosal and systemic cytotoxic T-lymphocyte responses. J. Virol. 2001, 75, 10139-10148. [CrossRef] [PubMed]

140. Zhang, H.; Fayad, R.; Wang, X.; Quinn, D.; Qiao, L. Human immunodeficiency virus type 1 gag-specific mucosal immunity after oral immunization with papillomavirus pseudoviruses encoding gag. J. Virol. 2004, 78, 10249-10257. [CrossRef] [PubMed]

141. Zhang, H.; Huang, Y.; Fayad, R.; Spear, G.T.; Qiao, L. Induction of mucosal and systemic neutralizing antibodies against human immunodeficiency virus type 1 (HIV-1) by oral immunization with bovine Papillomavirus-HIV-1 gp41 chimeric virus-like particles. J. Virol. 2004, 78, 8342-8348. [CrossRef] [PubMed]

142. Huang, Y.; Fayad, R.; Smock, A.; Ullrich, A.M.; Qiao, L. Induction of mucosal and systemic immune responses against human carcinoembryonic antigen by an oral vaccine. Cancer Res. 2005, 65, 6990-6999. [CrossRef] [PubMed]

143. Lu, W.; Andrieu, J.M. In vitro human immunodeficiency virus eradication by autologous CD8(+) T cells expanded with inactivated-virus-pulsed dendritic cells. J. Virol. 2001, 75, 8949-8956. [CrossRef] [PubMed]

144. Whiteside, T.L.; Piazza, P.; Reiter, A.; Stanson, J.; Connolly, N.C.; Rinaldo, C.R., Jr.; Riddler, S.A. Production of a dendritic cell-based vaccine containing inactivated autologous virus for therapy of patients with chronic human immunodeficiency virus type 1 infection. Clin. Vaccine Immunol. 2009, 16, 233-240. [CrossRef] [PubMed]

145. Gil, C.; Climent, N.; Garcia, F.; Hurtado, C.; Nieto-Marquez, S.; Leon, A.; Garcia, M.T.; Rovira, C.; Miralles, L.; Dalmau, J.; et al. Ex vivo production of autologous whole inactivated HIV-1 for clinical use in therapeutic vaccines. Vaccine 2011, 29, 5711-5724. [CrossRef] [PubMed] 
146. Huang, X.L.; Fan, Z.; Zheng, L.; Borowski, L.; Li, H.; Thomas, E.K.; Hildebrand, W.H.; Zhao, X.Q.; Rinaldo, C.R., Jr. Priming of human immunodeficiency virus type 1 (HIV-1)-specific CD8+ T cell responses by dendritic cells loaded with HIV-1 proteins. J. Infect. Dis. 2003, 187, 315-319. [CrossRef] [PubMed]

147. Huang, X.L.; Fan, Z.; Colleton, B.A.; Buchli, R.; Li, H.; Hildebrand, W.H.; Rinaldo, C.R., Jr. Processing and presentation of exogenous HLA class I peptides by dendritic cells from human immunodeficiency virus type 1-infected persons. J. Virol. 2005, 79, 3052-3062. [CrossRef] [PubMed]

148. Chassin, D.; Andrieu, M.; Cohen, W.; Culmann-Penciolelli, B.; Ostankovitch, M.; Hanau, D.; Guillet, J.G. Dendritic cells transfected with the nef genes of HIV-1 primary isolates specifically activate cytotoxic T lymphocytes from seropositive subjects. Eur. J. Immunol. 1999, 29, 196-202. [CrossRef]

149. Weissman, D.; Ni, H.; Scales, D.; Dude, A.; Capodici, J.; McGibney, K.; Abdool, A.; Isaacs, S.N.; Cannon, G.; Kariko, K. HIV gag mRNA transfection of dendritic cells (DC) delivers encoded antigen to MHC class I and II molecules, causes DC maturation, and induces a potent human in vitro primary immune response. J. Immunol. 2000, 165, 4710-4717. [CrossRef] [PubMed]

150. Kavanagh, D.G.; Kaufmann, D.E.; Sunderji, S.; Frahm, N.; Le Gall, S.; Boczkowski, D.; Rosenberg, E.S.; Stone, D.R.; Johnston, M.N.; Wagner, B.S.; et al. Expansion of HIV-specific CD4+ and CD8+ T cells by dendritic cells transfected with mRNA encoding cytoplasm- or lysosome-targeted Nef. Blood 2006, 107, 1963-1969. [CrossRef] [PubMed]

151. Van Gulck, E.R.; Ponsaerts, P.; Heyndrickx, L.; Vereecken, K.; Moerman, F.; De Roo, A.; Colebunders, R.; Van den Bosch, G.; Van Bockstaele, D.R.; Van Tendeloo, V.F.; et al. Efficient stimulation of HIV-1-specific T cells using dendritic cells electroporated with mRNA encoding autologous HIV-1 Gag and Env proteins. Blood 2006, 107, 1818-1827. [CrossRef] [PubMed]

152. Allard, S.D.; Pletinckx, K.; Breckpot, K.; Heirman, C.; Bonehill, A.; Michiels, A.; van Baalen, C.A.; Gruters, R.A.; Osterhaus, A.D.; Lacor, P.; et al. Functional T-cell responses generated by dendritic cells expressing the early HIV-1 proteins Tat, Rev and Nef. Vaccine 2008, 26, 3735-3741. [CrossRef] [PubMed]

153. Van Gulck, E.R.; Vanham, G.; Heyndrickx, L.; Coppens, S.; Vereecken, K.; Atkinson, D.; Florence, E.; Kint, I.; Berneman, Z.N.; Van Tendeloo, V. Efficient in vitro expansion of human immunodeficiency virus (HIV)-specific T-cell responses by gag mRNA-electroporated dendritic cells from treated and untreated HIV type 1-infected individuals. J. Virol. 2008, 82, 3561-3573. [CrossRef] [PubMed]

154. Routy, J.P.; Boulassel, M.R.; Yassine-Diab, B.; Nicolette, C.; Healey, D.; Jain, R.; Landry, C.; Yegorov, O.; Tcherepanova, I.; Monesmith, T.; et al. Immunologic activity and safety of autologous HIV RNA-electroporated dendritic cells in HIV-1 infected patients receiving antiretroviral therapy. Clin. Immunol. 2010, 134, 140-147. [CrossRef] [PubMed]

155. Engelmayer, J.; Larsson, M.; Lee, A.; Lee, M.; Cox, W.I.; Steinman, R.M.; Bhardwaj, N. Mature dendritic cells infected with canarypox virus elicit strong anti-human immunodeficiency virus CD8+ and CD4+ T-cell responses from chronically infected individuals. J. Virol. 2001, 75, 2142-2153. [CrossRef] [PubMed]

156. Guerra, S.; Najera, J.L.; Gonzalez, J.M.; Lopez-Fernandez, L.A.; Climent, N.; Gatell, J.M.; Gallart, T.; Esteban, M. Distinct gene expression profiling after infection of immature human monocyte-derived dendritic cells by the attenuated poxvirus vectors MVA and NYVAC. J. Virol. 2007, 81, 8707-8721. [CrossRef] [PubMed]

157. Guerra, S.; Gonzalez, J.M.; Climent, N.; Reyburn, H.; Lopez-Fernandez, L.A.; Najera, J.L.; Gomez, C.E.; Garcia, F.; Gatell, J.M.; Gallart, T.; et al. Selective induction of host genes by MVA-B, a candidate vaccine against HIV / AIDS. J. Virol. 2010, 84, 8141-8152. [CrossRef] [PubMed]

158. Climent, N.; Guerra, S.; Garcia, F.; Rovira, C.; Miralles, L.; Gomez, C.E.; Pique, N.; Gil, C.; Gatell, J.M.; Esteban, M.; et al. Dendritic cells exposed to MVA-based HIV-1 vaccine induce highly functional HIV-1-specific CD8(+) T cell responses in HIV-1-infected individuals. PLoS ONE 2011, 6, e19644. [CrossRef] [PubMed]

159. Pion, M.; Serramia, M.J.; Diaz, L.; Bryszewska, M.; Gallart, T.; Garcia, F.; Gomez, R.; de la Mata, F.J.; Munoz-Fernandez, M.A. Phenotype and functional analysis of human monocytes-derived dendritic cells loaded with a carbosilane dendrimer. Biomaterials 2010, 31, 8749-8758. [CrossRef] [PubMed]

160. Lapenta, C.; Santini, S.M.; Logozzi, M.; Spada, M.; Andreotti, M.; Di Pucchio, T.; Parlato, S.; Belardelli, F. Potent immune response against HIV-1 and protection from virus challenge in hu-PBL-SCID mice immunized with inactivated virus-pulsed dendritic cells generated in the presence of IFN-alpha. J. Exp. Med. 2003, 198, 361-367. [CrossRef] [PubMed] 
161. Lu, W.; Wu, X.; Lu, Y.; Guo, W.; Andrieu, J.M. Therapeutic dendritic-cell vaccine for simian AIDS. Nat. Med. 2003, 9, 27-32. [CrossRef] [PubMed]

162. Yoshida, A.; Tanaka, R.; Murakami, T.; Takahashi, Y.; Koyanagi, Y.; Nakamura, M.; Ito, M.; Yamamoto, N.; Tanaka, Y. Induction of protective immune responses against R5 human immunodeficiency virus type 1 (HIV-1) infection in hu-PBL-SCID mice by intrasplenic immunization with HIV-1-pulsed dendritic cells: Possible involvement of a novel factor of human CD4(+) T-cell origin. J. Virol. 2003, 77, 8719-8728. [PubMed]

163. Aline, F.; Brand, D.; Bout, D.; Pierre, J.; Fouquenet, D.; Verrier, B.; Dimier-Poisson, I. Generation of specific Th1 and CD8+ T-cell responses by immunization with mouse CD8+ dendritic cells loaded with HIV-1 viral lysate or envelope glycoproteins. Microbes Infect. 2007, 9, 536-543. [CrossRef] [PubMed]

164. Kundu, S.K.; Engleman, E.; Benike, C.; Shapero, M.H.; Dupuis, M.; van Schooten, W.C.; Eibl, M.; Merigan, T.C. A pilot clinical trial of HIV antigen-pulsed allogeneic and autologous dendritic cell therapy in HIV-infected patients. AIDS Res. Hum. Retroviruses 1998, 14, 551-560. [CrossRef] [PubMed]

165. Lu, W.; Arraes, L.C.; Ferreira, W.T.; Andrieu, J.M. Therapeutic dendritic-cell vaccine for chronic HIV-1 infection. Nat. Med. 2004, 10, 1359-1365. [CrossRef] [PubMed]

166. Garcia, F.; Lejeune, M.; Climent, N.; Gil, C.; Alcami, J.; Morente, V.; Alos, L.; Ruiz, A.; Setoain, J.; Fumero, E.; et al. Therapeutic immunization with dendritic cells loaded with heat-inactivated autologous HIV-1 in patients with chronic HIV-1 infection. J. Infect. Dis. 2005, 191, 1680-1685. [CrossRef] [PubMed]

167. Ide, F.; Nakamura, T.; Tomizawa, M.; Kawana-Tachikawa, A.; Odawara, T.; Hosoya, N.; Iwamoto, A. Peptide-loaded dendritic-cell vaccination followed by treatment interruption for chronic HIV-1 infection: A phase 1 trial. J. Med. Virol. 2006, 78, 711-718. [CrossRef] [PubMed]

168. Connolly, N.C.; Whiteside, T.L.; Wilson, C.; Kondragunta, V.; Rinaldo, C.R.; Riddler, S.A. Therapeutic immunization with human immunodeficiency virus type 1 (HIV-1) peptide-loaded dendritic cells is safe and induces immunogenicity in HIV-1-infected individuals. Clin. Vaccine Immunol. 2008, 15, 284-292. [CrossRef] [PubMed]

169. Gandhi, R.T.; O’Neill, D.; Bosch, R.J.; Chan, E.S.; Bucy, R.P.; Shopis, J.; Baglyos, L.; Adams, E.; Fox, L.; Purdue, L.; et al. A randomized therapeutic vaccine trial of canarypox-HIV-pulsed dendritic cells $v s$. canarypox-HIV alone in HIV-1-infected patients on antiretroviral therapy. Vaccine 2009, 27, 6088-6094. [CrossRef] [PubMed]

170. Kloverpris, H.; Karlsson, I.; Bonde, J.; Thorn, M.; Vinner, L.; Pedersen, A.E.; Hentze, J.L.; Andresen, B.S.; Svane, I.M.; Gerstoft, J.; et al. Induction of novel CD8+ T-cell responses during chronic untreated HIV-1 infection by immunization with subdominant cytotoxic T-lymphocyte epitopes. AIDS 2009, 23, 1329-1340. [CrossRef] [PubMed]

171. Garcia, F.; Climent, N.; Assoumou, L.; Gil, C.; Gonzalez, N.; Alcami, J.; Leon, A.; Romeu, J.; Dalmau, J.; Martinez-Picado, J.; et al. A therapeutic dendritic cell-based vaccine for HIV-1 infection. J. Infect. Dis. 2011, 203, 473-478. [CrossRef] [PubMed]

172. Routy, J.-P.; Angel, J.; Vezina, S.; Tremblay, C.; Loutfy, M.; Gill, J.; Baril, J.G.; Smaill, F.S.; Jain, R.; Nicolette, C. Final Analysis of a Phase 2 Study of an Autologous Dendritic Cell Immunotherapy (AGS-004) Showed Positive Outcomes in Primary Endpoint of Viral Load Control, and Favorable Safety and Immunogenicity Profile, in Subjects Undergoing Structured Treatment Interruption of ART (Abstract 385). In Proceedings of the 18th Conference on Retroviruses and Opportunistic Infections, Boston, MA, USA, 27 February-22 March 2011.

173. Allard, S.D.; De Keersmaecker, B.; de Goede, A.L.; Verschuren, E.J.; Koetsveld, J.; Reedijk, M.L.; Wylock, C.; De Bel, A.V.; Vandeloo, J.; Pistoor, F.; et al. A phase I/IIa immunotherapy trial of HIV-1-infected patients with Tat, Rev and Nef expressing dendritic cells followed by treatment interruption. Clin. Immunol. 2012, 142, 252-268. [CrossRef] [PubMed]

174. Van Gulck, E.; Vlieghe, E.; Vekemans, M.; Van Tendeloo, V.F.; Van De Velde, A.; Smits, E.; Anguille, S.; Cools, N.; Goossens, H.; Mertens, L.; et al. mRNA-based dendritic cell vaccination induces potent antiviral T-cell responses in HIV-1-infected patients. AIDS 2012, 26, F1-F12. [CrossRef] [PubMed]

175. Garcia, F.; Climent, N.; Guardo, A.C.; Gil, C.; Leon, A.; Autran, B.; Lifson, J.D.; Martinez-Picado, J.; Dalmau, J.; Clotet, B.; et al. A Dendritic Cell-Based Vaccine Elicits T Cell Responses Associated with Control of HIV-1 Replication. Sci. Transl. Med. 2013. [CrossRef] [PubMed] 
176. Lévy, Y.; Thiébaut, R.; Montes, M.; Lacabaratz, C.; Sloan, L.; King, B.; Pérusat, S.; Harrod, C.; Cobb, A.; Roberts, L.K.; et al. Dendritic cell-based therapeutic vaccine elicits polyfunctional HIV-specific T-cell immunity associated with control of viral load. Eur. J. Immunol. 2014, 44, 2802-2810. [CrossRef] [PubMed]

177. Tcherepanova, I.; Krisko, J.; Harris, J.; Gamble, A.; Lewis, W.; DeBenedette, M.; Nicolette, C. Polyvalent immune responses correlate with lower number of HIV-infected CD4 T cells in chronically infected subjects treated with autologous RNA pulsed DC therapy. In Proceedings of the 8th IAS Conference on HIV Pathogenesis, Treatment and Prevention, Vancouver, BC, Canada, 19-22 July 2015.

178. Gandhi, R.T.; Kwon, D.S.; Macklin, E.A.; Shopis, J.R.; McLean, A.P.; McBrine, N.; Theresa Flynn, A.N.; Peter, L.; Sbrolla, A.; Kaufmann, D.E.; et al. Immunization of HIV-1-infected Persons with Autologous Dendritic Cells Transfected with mRNA Encoding HIV-1 Gag and Nef: Results of a Randomized, Placebo-Controlled Clinical Trial. J. Acquir. Immune Defic. Syndr. 2015. [CrossRef] [PubMed]

179. Macatangay, B.J.; Riddler, S.A.; Wheeler, N.D.; Spindler, J.; Lawani, M.; Hong, F.; Buffo, M.J.; Whiteside, T.L.; Kearney, M.F.; Mellors, J.W.; et al. Therapeutic vaccination with dendritic cells loaded with autologous HIV-1-infected apoptotic cells. J. Infect. Dis. 2015. [CrossRef] [PubMed]

180. Rossio, J.L.; Esser, M.T.; Suryanarayana, K.; Schneider, D.K.; Bess, J.W., Jr.; Vasquez, G.M.; Wiltrout, T.A.; Chertova, E.; Grimes, M.K.; Sattentau, Q.; et al. Inactivation of human immunodeficiency virus type 1 infectivity with preservation of conformational and functional integrity of virion surface proteins. J. Virol. 1998, 72, 7992-8001. [PubMed]

181. Larsson, M.; Fonteneau, J.F.; Lirvall, M.; Haslett, P.; Lifson, J.D.; Bhardwaj, N. Activation of HIV-1 specific CD4 and CD8 T cells by human dendritic cells: Roles for cross-presentation and non-infectious HIV-1 virus. AIDS 2002, 16, 1319-1329. [CrossRef] [PubMed]

182. Frank, I.; Santos, J.J.; Mehlhop, E.; Villamide-Herrera, L.; Santisteban, C.; Gettie, A.; Ignatius, R.; Lifson, J.D.; Pope, M. Presentation of exogenous whole inactivated simian immunodeficiency virus by mature dendritic cells induces CD4+ and CD8+ T-cell responses. J. Acquir. Immune Defic. Syndr. 2003, 34, 7-19. [CrossRef] [PubMed]

183. Letvin, N.L.; Walker, B.D. Immunopathogenesis and immunotherapy in AIDS virus infections. Nat. Med. 2003, 9, 861-866. [CrossRef] [PubMed]

184. Hel, Z.; Nacsa, J.; Tryniszewska, E.; Tsai, W.P.; Parks, R.W.; Montefiori, D.C.; Felber, B.K.; Tartaglia, J.; Pavlakis, G.N.; Franchini, G. Containment of simian immunodeficiency virus infection in vaccinated macaques: Correlation with the magnitude of virus-specific pre- and postchallenge CD4+ and CD8+ T cell responses. J. Immunol. 2002, 169, 4778-4787. [CrossRef] [PubMed]

185. Ostrowski, M.A.; Justement, S.J.; Ehler, L.; Mizell, S.B.; Lui, S.; Mican, J.; Walker, B.D.; Thomas, E.K.; Seder, R.; Fauci, A.S. The role of CD4+ T cell help and CD40 ligand in the in vitro expansion of HIV-1-specific memory cytotoxic CD8+ T cell responses. J. Immunol. 2000, 165, 6133-6141. [CrossRef] [PubMed]

186. Day, C.L.; Walker, B.D. Progress in defining CD4 helper cell responses in chronic viral infections. J. Exp. Med. 2003, 198, 1773-1777. [CrossRef] [PubMed]

187. Kaech, S.M.; Ahmed, R. Immunology. CD8 T cells remember with a little help. Science 2003, 300, $263-265$. [CrossRef] [PubMed]

188. McHeyzer-Williams, L.J.; McHeyzer-Williams, M.G. Antigen-specific memory B cell development. Annu. Rev. Immunol. 2005, 23, 487-513. [CrossRef] [PubMed]

(C) 2016 by the authors; licensee MDPI, Basel, Switzerland. This article is an open access article distributed under the terms and conditions of the Creative Commons by Attribution (CC-BY) license (http://creativecommons.org/licenses/by/4.0/). 